\title{
La Vida de Santa Oria de Gonzalo de Berceo: nueva interpretación y nuevos datos
}

\author{
JOAQUÍN GIMENO CASALDUERO
}

Universidad de California

La Vida de Santa Oria trata de una monja benedictina que vivió reclusa en San Millán de Suso. Sigue, según dice Berceo, un documento anterior, que no ha llegado hasta nosotros, escrito por Muño, confesor de la santa. La obra, incompleta, presenta ahora doscientas cinco estrofas; pero las veintiuna últimas parecen añadidas: quizá por el mismo Berceo, como muchos críticos suponen. Nosotros prescindiremos de ellas, sin embargo, no porque dudemos de que sean de Berceo (tampoco lo afirmamos), sino porque en nuestra opinión constituyen una versión segunda, y aquí nos proponemos estudiar únicamente la primera. El poema consta, por lo tanto, de ciento ochenta y cuatro tetrámetros monorrimos, y se divide en tres partes principales, construida cada una en torno a una visión sobrenatural de la protagonista -I, estrs. 25-109; II, estrs. 110-136; III, estrs. 137-179-. Además, comienza con una introducción -estrs. 1-24- y termina con un epílogo -estrs. 180-184'.

1 Utilizamos la edición de Brian Dutton al referirnos a las obras de Berceo: Gonzalo de Berceo, Obras completas, London, Tamesis. Hay que agradecer a Dutton su extraordinaria labor en relación con la poesía de Berceo: sus ediciones y estudios son imprescindibles. Sobre la Vida de Santa Oria (V, 1981) opina Dutton que el añadido se debe probablemente al mismo Muño (p. 93); cambia de lugar, por otra parte, la estrofa 184, que es en su edición la última. En nuestro trabajo indicaremos junto a las citas el número de la estrofa. 
La introducción presenta a Santa Oria, cuenta su vida hasta el momento en que empiezan las visiones; es decir, habla de su patria y de sus padres, refiere su entrada en el monasterio, enumera sus virtudes, $\mathrm{y}$ atribuye a esas virtudes los méritos por los que gana la felicidad eterna tras la muerte y la gracia de la visión en esta vida. Terminada la introducción, se desarrollan las tres partes - las tres visiones - sobre las que el poema se levanta. En la primera, visita el cielo Santa Oria y contempla a sus habitantes, su organización y su estructura; contempla también el premio que ha ganado con sus obras y que se le reserva si sabe mantenerlo. En la segunda visión, es María, rodeada de vírgenes, la que visita a la penitente para comunicarle que sus nuevas oraciones y sus sacrificios le han asegurado el premio y que se acerca su muerte, por lo tanto. En la visión tercera, se traslada Oria al Monte de los Olivos y comienza a gozar en él de la eterna bienaventuranza. Es entonces, al terminar la visita, cuando tiene lugar la muerte y enterramiento de la reclusa. El breve epílogo certifica por eso su triunfo.

Lo esencial en el poema es la muerte, por lo tanto. De ahí que ésta, convirtiéndose en meta de la obra, determine episodios y elementos. Avanzan hacia esa meta las distintas partes: la muerte no es sólo el triunfo de la virgen, es también el final glorioso del poema. La obra toda se organiza en función de ese momento. La introducción apunta los méritos de Oria para fijar así dos objetivos: llegar al cielo tras la muerte y visitar el cielo en vida. El primer objetivo, como es lógico, se consigue en el desenlace: la entrada definitiva de la reclusa en el paraíso cierra la acción y culmina el movimiento. El segundo objetivo, por otro lado, al convertirse en causa del primero - puesto que con la memoria de la experiencia y con la seguridad de sus augurios sostiene la conducta de la santaamplía su propia función y, como resultado, extiende su presencia a través de los distintos núcleos de la obra.

De ahí la importancia y la extensión -ochenta y cinco estrofas- de la visión primera: es ella la que realiza la visita en vida y la que asegura con su influjo la gloria perdurable. De ahí también que se supediten a ella las dos visiones posteriores. La visión segunda muestra cómo la visita al paraíso mantiene y acentúa 
la virtud de Oria y cómo, por su causa, la muerte y el premio se aproximan. La visión tercera, por su parte, sirve de marco dentro del cual la muerte llega a la reclusa y el premio se recibe. El epílogo, por otro lado, testimonia la glorificación de la santa.

Es evidente, pues, la importancia de la visión inicial: determina, en cuanto ejecutora de la función que rige el desarrollo, los otros núcleos e influye en los otros elementos. Ella conecta, además, los distintos materiales dando a la diversidad armonía; a la variedad, unión; al conjunto, sentido. Voy a dedicar, por eso, parte de mi trabajo al estudio de la visión primera; pretendiendo con ese estudio determinar su función dentro del propósito general de la obra. Comenzaré por establecer ese propósito; para establecerlo me referiré a algunas teorías de la crítica: a aquellas que recogen en cierto modo las distintas opiniones. Presentaré, además, al enunciarlas, mi reacción y mis comentarios.

T. Anthony Perry, en su libro Art and Meaning in Berceo's «Vida de Santa Oria» (New Haven and London, Yale University Press, 1968, p. 55), opina que se escribió el poema para fomentar la piedad del pueblo, para dar ejemplos generales de conducta y para recomendar de una manera determinada el desprecio de las cosas del mundo. Creo innegable que la Vida de Santa Oria se escribió para promover la piedad del pueblo, pero en eso coincide con cualquier obra popular religiosa. Esa afirmación, por lo tanto, no descubre el propósito definido del poema. Más difícil resulta admitir las afirmaciones de Perry cuando señalan un propósito determinado: enseña la obra que el camino del cielo consiste en el desprecio de las cosas del mundo. Es evidente que se nos dice que mediante el desprecio de las cosas del mundo llega al cielo Santa Oria; pero de ahí no se sigue que se recomiende a los demás ese camino ni que se limite al desprecio del mundo los méritos de la reclusa, puesto que la oración, la humildad y la penitencia juegan un papel decisivo en los méritos de Oria.

John Walsh, en su artículo «A possible Source for Berceo's Vida de Santa Oria» (MLN, 87 [1972], p. 301), siguiendo afirmacio- 
nes de Brian Dutton ${ }^{2}$, opina que el poema se escribió para atraer peregrinos en un momento en el que el monasterio de San Millán atravesaba una crisis económica. Creo que tiene razón Dutton cuando dice que en parte Berceo compone sus poemas por motivos propagandísticos; creo, por eso, que Walsh no se equivoca cuando atribuye esta intención al poema que estudiamos. Sin embargo, me parece que en el caso de Santa Oria no pudo ser éste el único ni el más importante de sus propósitos.

Si nos fijamos en los dos poemas que se relacionan especialmente con el monasterio de Berceo (la Vida de San Millán y la Vida de Santa Oria) notaremos enseguida la diferencia de carácter entre los dos protagonistas. San Millán aparece con una importancia extraordinaria; una importancia que amplía su función y que transforma su figura convirtiendo en héroe épico al ermitaño. Esto hace que se introduzca en el poema una digresión de ciento veinte estrofas (estrs. 361-480) que narra un momento capital de la historia de León y de Castilla: el tributo de las cien doncellas. Se presenta a San Millán como protector de Castilla, parangonándole en dignidad y en prestigio con el apóstol Santiago que aparece como protector de León. No creo que se pueda magnificar más su nombre y su categoria, puesto que se le equipara con el que era para los españoles el apóstol por antonomasia. Por otra parte, los milagros de San Millán, innumerables y de todo tipo, extendiendo su fama y atrayendo enfermos y necesitados, le convierten en el protector, por así decirlo, de la cristiandad entera. Narra Berceo muchos de esos milagros; en realidad, a referirlos se dedican los dos últimos libros de los tres que componen la obra. Y como a las reliquias de San Millán se atribuyen los milagros, y como éstas reposan en el monasterio de Berceo, se convierte el monasterio en centro de peregrinaje. Se comprende, pues, que se escogiera a San Millán para escribir un poema propagandístico; pero, ¿qué se puede decir, en cambio, de la pobre Santa Oria, de la humilde reclusa que pasó la vida encerrada en una celda? Santa Oria no podía ofrecer hazañas épicas a Castilla ni prodigios a la población del

2 En su edición de La vida de San Millán de la Cogolla (I, 1967). 
monasterio. Se trata de una desconocida emparedada que habita en el silencio hasta su muerte. Y a su muerte continúa silenciosa: ni un milagro siquiera para que Berceo convocara con él a enfermos o a afligidos. No, nos parece difícil que Berceo escribiera la Vida de Santa Oria para atraer peregrinos a la tumba de la santa, para salvar la deteriorada economía de San Millán de Suso.

James F. Burke, en su artículo "The Four Comings of Christ in Gonzalo de Berceo's Vida de Santa Oria) (Speculum, 48 [1973], p. 312), opina que Berceo escribe el poema con el propósito de ofrecer, mediante el ejemplo concreto de Oria y utilizando el significado de ciertas fiestas religiosas, un principio definido de conducta: la necesidad de adecuar la vida individual con la de Cristo para recibir la gracia de Dios y salvarse. Lo que dice Burke no nos parece equivocado. Es cierto que la vida de Oria se acomoda a la de Cristo, y que éste la ilumina y la sostiene con su gracia. De ahí puede sacarse una conclusión general utilizable: la imitación de Cristo, al merecer el apoyo de la gracia, facilita el triunfo tras la muerte. Lo mismo podría decirse, sin embargo, de las otras vidas de Berceo. San Millán, Santo Domingo o San Lorenzo son de alguna forma nuevos Cristos: siguen sus pasos, ejercen sus actividades, imitan sus virtudes, repiten su martirio. Y esa semejanza -aunque no está sostenida entonces en festividades litúrgicas como ve Burke en Santa Oria - la señala Berceo con más fuerza sin duda en las otras vidas.

Aldo Ruffinatto, en su libro La struttura del racconto agiografico nella letteratura spagnola delle origini (Torino, Litografia Artigiana, 1974), rompe con Walsh, al que no nombra, y sobre todo con Dutton, al que cita. No puede ser, advierte, propagandístico el propósito del poema (pp. 67-68). Opina, en cambio, que la obra -que se caracteriza por la total ausencia de actividad taumatúrgica - no se dirige a un número amplio de lectores, sino a un reducido grupo de personas, a las «sorores tocanegradas» que llenaban muchos conventos benedictinos de entonces: «Non avremo difficoltà ad affermare che il poemetto di Santa Oria, proprio perché esente dalle finalità propagandistiche e pubblicitarie che ispiravano gli altri testi agiografici, non era indirizzato ad un 
vasto pubblico, ma ad una ristretta categoria di persone, di profondi costumi religiosi e di sesso femminile. Alle monache, quindi, alle cosiddette sorores tocanegradas che popolavano i numerosi conventi benedettini della Spagna del XIII secolo» (p. 70). Comparto la opinión de Ruffinatto.

En resumen, me parece que Berceo compone la Vida de Santa Oria no sólo pensando en fomentar la piedad del pueblo o en extender la fama de San Millán de Suso o en dar ejemplos generales de conducta, sino que la escribe además (dirigiéndose a un pequeño grupo, como afirma Ruffinato) para animar a las monjas de la época: recluidas en monasterios como el de San Millán de la Cogolla, entregadas a la vida contemplativa, dedicadas a la castidad y al sacrificio, ajenas a los negocios mundanales, sometidas a una vida monótona que - de acuerdo con los cánones del siglo - nada tenía de heroica ni admirable. Necesitaban esas monjas justificar ante sí mismas la razón de su existencia, su vida aparentemente improductiva, sorda a los sufrimientos del resto de los fieles. Necesitaban, por otro lado, auxilio exterior que las sostuviera. Y para satisfacer esas necesidades se escribe la Vida de Santa Oria: para animar a las monjas a ser pacientes, a resistir hasta el final su cansada y difícil existencia. El poema muestra, por eso, el trabajo que a lo largo de la vida y la victoria que en el instante de la muerte aguardan a las reclusas, y anima a éstas - como resultado- a mantener la profesión que han elegido.

\section{VISION PRIMERA}

Esas monjas necesitaban además ejercicios espirituales que mitigaran la fatiga provocada por su reclusión interminable, prácticas que ahuyentasen las tentaciones de que a menudo se quejaban. Pensando en ello, me parece, y como ejercicio espiritual, se compone la visión primera. La Vida, naturalmente, no es en este sentido innovadora: los Santos Padres habían utilizado el recurso al hablar a las vírgenes y al escribir para ellas reglas y consejos. Entre los Santos Padres nos fijaremos primero en San Jerónimo, quien, 
hacia el año 384, escribe la más famosa quizá de sus epístolas, la que trata de la virginidad y se dirige a Eustoquia ${ }^{3}$.

San Jerónimo, conocedor de los problemas de los que se consagran a la castidad, a la oración y al sacrificio, termina su epístola con un consejo definido: en las tentaciones y en los momentos de fatiga debe la virgen representarse el premio que espera tras la muerte: "Trasládate al paraíso con la mente» ${ }^{4}$, aconseja a la joven Eustoquia. Eso es precisamente lo que hace la Vida de Santa Oria en la visión primera ${ }^{5}$. Y lo hace partiendo de la epístola y apoyándose en ella muchas veces. La principal diferencia es que San Jerónimo aconseja trasladarse mentalmente, y para facilitar ese traslado refiere, como ejemplo, una visita imaginaria; la Vida, en cambio, describe una visita real, traslada de hecho a Santa Oria. De modo semejante, la visión primera -el núcleo que sostiene el desarrollo de la obra - al referir una visita real al paraíso obliga a las reclusas a trasladarse al cielo con la mente, de acuerdo con lo que San Jerónimo aconseja y en busca del provecho que él promete: perseverancia para vencer la tentación y la fatiga. "Sal, te pido, por un momento de tu cuerpo", había dicho San Jerónimo, «y pon ante tus ojos el premio [que has de recibir] por los presentes trabajos». Eso es lo que hace Santa Oria, «salir del cuerpo»; nos lo recuerda el poema cuando explica el regreso de la santa: «Prisiéronla las mártires que ante la guiaron [...] / en muy poquiello rato al cuerpo la tornaron" (estr. 108). Y sube al cielo Santa Oria, como afirman las vírgenes al invitarla, para observar - para «poner ante los ojos», como dice San Jerónimo- el premio que a su presente trabajo se reserva: «Combidarte venimos com a nuestra hermana [...] / que subas a los Cielos e que veas qué gana / el servicio que fazes e la saya de lana» (estr. 33).

3 Ad Eustochium en Cartas de San Jerónimo, I, Madrid, BAC, 1962, pp. 157-207. Indico en adelante tras la cíta el número de la página.

4 «Ad paradisum mente transgredere», p. 207.

5 Entiendo por Vida de Santa Oria tanto el original latino como el poema de Berceo. 
La visión, por otro lado, se compone de acuerdo con lo que relata la epístola. Oigamos otra vez a San Jerónimo:

Sal, te pido, por un momento de tu cuerpo y pon ante tus ojos el premio [que has de recibir] por los presentes trabajos. [...] ¿Cómo será aquel día cuando María, Madre del Señor, te salga a recibir acompañada por los coros de vírgenes? [...] Entonces Tecla volará feliz a abrazarte [...] entonces el esposo te saldrá al encuentro [...] entonces se maravillarán los ángeles [...] entonces te recibirá también el otro coro de la castidad: Sara vendrá con las casadas; Ana, hija de Famuel, con las viudas. Allí estarán, como en dos grupos diferentes, el de la carne y el del espíritu, tus dos madres. Aquélla se alegrará de haberte concebido, ésta se regocijará de haberte enseñado ${ }^{6}$.

El viaje de Santa Oria se organiza siguiendo a San Jerónimo, pero con ciertas variaciones que lo amplían y que por lo general lo sitúan en la región en donde transcurrió la vida de la santa. Comienza la visión con la visita de tres vírgenes (Eulalia, Ágata y Cecilia) que sustituyen a las tres mujeres que representan tipos distintos de castidad en la evocación de San Jerónimo; es decir, a Tecla (célibes), a Sara (casadas) y a Ana (viudas). Dice así el poema: "Vido tres santas vírgines de grant auctoridat, / todas tres fueron mártires en poquiella edat: / Agatha en Catanna, essa rica cibdat, / Olalia en Melérida, ninna de grant beldat. / Cecilia fue tercera, una mártir preciosa, / que de don Jhesu Christo quiso seer esposa» (estrs. 27-28). Las tres vírgenes, convirtiéndose en guías de Santa Oria, la llevan con ellas a los cielos.

El poema de Berceo diferencia inmediatamente su visión de la de San Jerónimo, cargando de importancia a la sociedad y a la jerarquía celestiales. No se trata de una ruptura con la epístola, sino de una diferente construcción y de un movimiento diferente. En San Jerónimo, los encuentros con seres celestiales sirven para

6 «Egredere, quaeso, paulisper e corpore, et praesentis laboris ante oculos tuos pinge mercedem. [...] Qualis erit illa dies, cum tibi Maria, mater Domini, choris occurret comitata uirgineis? [...] Tunc Thecla in tuos laeta uolabit amplexus. Tunc et ipse sponsus occurret [...] tunc angeli mirabuntur [...] tunc et alius castitatis chorus occurret: Sara cum nuptis ueniet, filia Phanuelis Anna cum uiduis. Erunt, ut in diuersis gregibus, carnis et spiritus, matres tuae. Laetabitur illa quod genuit; exultabit ista quod docuit», pp. 206-207. 
ponderar la gloria futura de la joven y para colocar a ésta en el coro de las vírgenes. Así, esos encuentros se entrelazan sin orden jerárquico ninguno y sin una intención abarcadora que vaya más allá de esos coros virginales. Es decir, no se trata de presentar el reino de los cielos: ni su complejidad ni su jerárquica estructura. En efecto, María, rodeada de las mujeres castas, es la primera en salir al encuentro de la joven; saluda inmediatamente, representado por Santa Tecla, el coro de las que siempre fueron vírgenes. Cristo, el esposo, aparece entonces para recibir a Eustoquia. A continuación los ángeles, para subrayar con su asombro la grandeza de la joven. Después, se vuelve a los coros de las mujeres castas para hacer que los dos restantes intervengan. Esto es lo que sucede: primero, Sara con las casadas; después, Ana con las viudas. Sucede sin prelación en absoluto, porque el orden tradicional era el inverso: primero, las viudas; luego, las casadas continentes. La inversión no significa que falte a San Jerónimo un sentido de jerarquía en lo que a la castidad respecta. Por el contrario, lo tiene y lo ha mostrado en sus epístolas e incluso en la misma que estamos estudiando. Me refiero al pasaje en el que coloca a la hermana de Eustoquia - la recién viuda Blesila- en el segundo grado de la castidad por su viudez precisamente ${ }^{7}$. Es decir, si San Jerónimo rompe el orden tradicional, no es porque no atribuya una dignidad distinta a los tres grados, sino porque al describir el cielo no se preocupa en absoluto de dibujar una sociedad jerarquizada.

Muy diferente es lo que sucede en la Vida de Santa Oria. Berceo expande el núcleo de San Jerónimo para darnos por entero la Jerusalén celeste. A la vez ordena y jerarquiza el complejo número de sus habitantes, y produce así un movimiento ascendente y graduado que lleva desde la celda de la reclusa - y a través de varios escalones- al trono de Cristo. Estos son los escalones que al sucederse crean la corte celestial que observa Oria: el de los sacerdotes, el de los obispos, el de las vírgenes, el de los mártires, el de los ermitaños, el de los apóstoles y evangelistas, el de Cristo. Sos-

7 «Et quanquam secundum pudicitiae gradum teneat», p. 171. 
tenido en esos siete escalones, por lo tanto, el cielo se organiza «de la misma manera», hemos dicho en otra parte, «como la sociedad del Gótico se establece: en una forma graduada, mediante un movimiento ascendente y progresivo, a través de una rigurosa jerarquía que se apunta en reyes, en emperador y en papa» ${ }^{8}$.

La Vida de Santa Oria debe, pues, a San Jerónimo el núcleo embrionario de la visión primera; debe también, como hemos notado ya, la estructura' del episodio. Hay otros elementos todavía que proceden de la epístola y que adornan ampliados y elaborados el viaje sobrenatural de la reclusa. Por ejemplo, en el coro de las mujeres castas que saludan a Eustoquia aparecen su madre y su maestra, sus dos madres como entonces las llama San Jerónimo: «Allí estarán como en dos grupos diferentes, el de la carne y el del espíritu, tus dos madres. Aquélla se alegrará de haberte concebido, ésta se regocijará de haberte enseñado». San Jerónimo coloca a la madre de Eustoquia en el cielo entre las mujeres castas, aunque ésta - Santa Paula - vive todavía. No es un problema, porque se trata de una visión imaginaria de lo que ha de suceder en el futuro. La Vida de Santa Oria, por otro lado, toma ese elemento, lo rehace y lo expande hasta constituir con él un episodio. Pero la Vida no alude para nada a la madre de la santa, porque ésta vive todavía $y$, como se trata de una visión real, no puede encontrar Santa Oria a su madre en el cielo, porque la deja en la tierra cuando la visión principia. Sin embargo, es a su maestra, a su madre según el espíritu en términos de San Jerónimo, a la que Oria encuentra entre las mujeres castas. Crea con ella Berceo un episodio delicioso que ha sido muy comentado por los críticos: pregunta Oria por Urraca, su maestra; se le responde que vive entre las vírgenes, y las vírgenes se apresuran a llamarla. Sus voces y la de Urraca se entrecruzan; pero el número de las esposas de Cristo es tan inmenso, que Oria y su maestra no pueden encontrarse. El episodio al provenir de San Jerónimo sostiene la visión en cierto modo; además, ya en manos de Berceo, magnifi-

8 Joaquin Gimeno Casalduero, «Berceo: composición y significado de la Vida de Santo Domingo de Silos», en La creación literaria de la Edad Media y del Renacimiento, Madrid, Porrúa Turanzas, 1977, pp. 12-13. 
ca de una manera emocional y gráfica el número de vírgenes; sirve, por último, para reducir la acción a unos términos geográficos conocidos.

Este deseo de colocar la acción en unos lugares conocidos - propio también de otras obras de Berceo- adopta aquí un especial carácter, precisamente porque el tipo de vida de la protagonista impide a ésta relacionarse con sus prójimos, como notamos al principio. De ahí la técnica actualizadora que se utiliza para describir el paraíso: puesto que Oria no se relaciona con sus prójimos, la relaciona el autor poblando el cielo de personajes coetáneos y oriundos de su región o de su monasterio. Logra el poema de ese modo humanizar a la reclusa, acercarla - a ella que no había ayudado nunca a nadie - a los que podrían necesitar su ayuda o su socorro.

Esta técnica caracteriza especialmente a la visión que estamos estudiando, pues en cada uno de los escalones que ordenan la sociedad celeste - con la excepción del de los mártires- ${ }^{9}$, se sitúan algunos personajes siempre de tierras de la santa. En efecto, en el primero - el de los sacerdotes - se nombra sólo a «quatro varones», todos ellos de la región del monasterio (estrs. 55-56). En el escalón segundo - el de los obispos- se nombra a tres abades de San Millán de Suso (estrs. 61-62). En el tercero -el de las vírgenes - se nombra, como ya dijimos, a Urraca, la maestra, y a

9 No se mantiene esta regla cuando se habla de los mártires, quizá por no haber personajes actuales que utilizar en la proximidad del monasterio. Acude entonces Berceo a San Esteban -es posible que por su calidad de protomártir-y a dos santos españoles (San Lorenzo y San Vicente) de los que había hablado en otras obras, y que acaso por eso podrían servir al propósito que con la técnica actualizadora se buscaba. Es cierto que en la elección de los tres personajes pudo haber otras razones que los introducirían en el ámbito de Oria. Leemos, por ejemplo, en la Vida de San Millán: «Cerca es de Cogolla, de parte de orient, / dos leguas sobre Nágera, al pie de Sant Lorent [...] / y nació sant Millán, esto sin falliment» (estr. 3). De ahí que afirme Dutton - apoyándose en la descripción geográfica que de San Millán hace Fray Prudencio Sandoval (Las fundaciones de San Benito, Madrid, Luis Sánchez, 1601)-, y en relación con el Martirio de San Lorenzo: «Tengo la fuerte sospecha de que tanto la fuente perdida como las coplas que faltan [...] contenían los milagros póstumos del santo [...] y que entre ellos había un portento que relaciona al santo con San Millán y da su nombre a la montañas (p. 166). De esa manera, decimos nosotros, San Lorenzo vendría a ocupar, en lo que a relación actualizadora se refiere, un puesto similar a los que ocupan los otros contemporáneos de la santa que aparecen en el cielo. Lo mismo podría suceder con San Vicente y San Esteban. 
Justa, la condiscípula de Oria (estr. 73). En el escalón cuarto -el de los mártires- aparecen San Esteban y los dos santos españoles a los que antes aludimos. En el escalón quinto -el de los ermitaños- aparecen cuatro personajes de la región de Oria, entre ellos el padre de la santa (estrs. 84-85). En el escalón sexto -el de los apóstoles-y en el séptimo - el de Cristo- no aparecen, naturalmente, otros personajes.

Es evidente, por otra parte, que tanto en la Vida de Santa Oria como en las otras vidas de Berceo y, en general, en las obras hagiográficas, se busca con esta técnica certificar lo extraordinario, dar a la acción verismo. Es decir, se busca asegurar la verdad de lo que se narra mediante el testimonio de espectadores conocidos; de la misma manera como se asegura mediante la alusión sistemática a las fuentes. Esa alusión sistemática a las fuentes, como ya se sabe, caracteriza las obras de Berceo ${ }^{10}$; en la Vida de Santa Oria, sin embargo, sus recursos adoptan una forma que ha sorprendido algunas veces a la crítica. De ahí que se haya tendido a interpretarlos como innovaciones técnicas que aproximan a Berceo a fórmulas narrativas posteriores. Lo que sucede es que Berceo no se limita a aludir directa o indirectamente a la obra que sigue en su trabajo; sino que introduce en el argumento de su historia al autor del manuscrito que traduce y versifica. $Y$ lo hace sin aviso, mediante una ruptura que confunde y desorienta. Ese autor que se convierte en personaje literario es a la vez narrador de lo que entonces se relata (estrs. 148-153 y 162-171). Se crea así una pluralidad de perspectivas, una dualidad de planos, que da al poema un trasfondo nuevo y que ayuda a sostener la ambigüedad que la experiencia onírica requiere. Sin embargo, y sean cuales sean las teorías de los críticos, lo que busca Berceo, además de verismo como siempre, es relacionar a la protagonista con los otros personajes que, por ser de la región del monasterio, la acercan a sus paisanos, la sacan de su aislamiento, la hụmanizan. Berceo, pues, al introducir al antiguo narrador, consigue su pro-

10 Sobre la relación del mester de clerecía con unas fuentes escritas véase el trabajo de Antonio Prieto, «En el mester fermoso de Berceo» en Coherencia y relevancia textual (De Berceo a Baroja), Madrid, Ahambra, 1980, p. 40. 
pósito: hace oír de boca de un testigo la extraordinaria experiencia que se narra y pone en contacto a la reclusa con el narrador de la experiencia.

Hay otros elementos que la Vida de Santa Oria debe también a San Jerónimo. La alegoría, por ejemplo; aunque ésta no se toma directamente de la epístola, sino que se crea con la ayuda de algunos de sus materiales. A Berceo la alegoría le interesa; la utiliza en sus obras a menudo y en algunas ocasiones ejecuta con ella trabajos significativos e influyentes. La Vida de Santa Oria no es una excepción ni mucho menos. La visión primera se organiza sobre una serie de elementos alegóricos que dan a la visita transcendencia. Recuérdese la paloma, la columna que hace de escalera, el prado que sirve de cima a la columna, las ventanas que se abren en los cielos, la silla que se reserva en el paraíso, la joven misteriosa que la guarda. Trataré ahora los tres primeros elementos y dejaré los otros para cuando estudie el tema de la oración al final de este trabajo.

En relación con la paloma. San Jerónimo, poco antes de aconsejar a Eustoquia y de dibujar para ella la visita imaginaria al paraíso, pondera - como preparación al episodio me parecela utilidad de meditar sobre el reino de los cielos y sobre el premio que en él aguarda a los perseverantes; porque esa meditación, dice San Jerónimo, despierta el deseo de subir como paloma a descansar en Cristo: «Pero cuando trata [la meditación] del reino de Cristo, de la felicidad futura y de la gloria venidera, verás decir a todos, con moderado suspiro y levantando los ojos al cielo: ¿Quién me dará plumas como a paloma para volar y para descansar?»"

La Vida de Santa Oria aprovecha el motivo. Puesto que la paloma tradicionalmente se identificaba con la virginidad y puesto que las leyendas sobre Santa Eulalia aseguraban que a su muerte

11 "Cum uero de regno Christi, de futura beatitudine, de gloria coeperit adnuntiare uentura, uideas cunctos moderato suspirio et oculis ad caelum leuatis intra se dicere: "Quis dabit mihi pinnas sicut columbae, et uolabo et requiescam?"'», p. 198. 
una paloma había salido de su boca y había volado al paraíso ${ }^{12}$, Berceo entrega una paloma a cada una de las vírgenes que acompañan a Oria, y hace que Santa Eulalia ceda la suya a la reclusa para que ésta con su vuelo (como en San Jerónimo) la lleve hasta lo alto:

Estas tres santas vírgines en Cielo coronadas tenién sendas palombas en sus manos alçadas. [...] (estr. 30)

«Fija» - dixo Olalia - «tú tal cosa non digas» [...] guarda esta palomba, todo lo ál oblida; tú vé do ella fuere, non seas decebida. [...] (estrs. 36-37)

Movióse la palomba, empeçó a volar, suso contra los cielos empeçó a pujar. [...] (estr. 40)

Don Oria la reclusa de Dios mucho amada [...] catando la palomba como bien acordada, subió en pos las otras a essa grant posada (estr. 49).

El vuelo de la paloma descifra, pues, el movimiento ascendente de Oria. Oria, siguiendo a la paloma de la virginidad y siguiendo por eso a las otras vírgenes, alcanza a éstas y entra también en el paraíso.

En relación con la columna. Las vírgenes y la reclusa suben al cielo en la Vida de Santa Oria mediante una escalera fabricada alrededor de una columna: «Alçó Oria los ojos arriba ond estava; / vido una columna, a los cielos pujava. [...] // Avié en la columpna escalones e gradas [...] / por tal suben las almas que son aventuradas» (estrs. 38-39). Berceo relaciona con la escala de Jacob esa escalera: «Quando durmié Jacob cerca de la carrera, /vido subir los ángeles por una escalera" (estr. 42). Es claro que para Berceo esa escalera significa la conducta, las obras buenas o malas con las que el hombre puede bajar fácilmente o subir con penoso esfuerzo: «Empeçaron las vírgines lazradas a sobir, / empeçólas la duenna reclusa a seguir» (estr. 41). En la Epistola a Eustoquia aparece con el mismo sentido la escala de Jacob, y permite con su presencia a San Jerónimo avisar contra los peligros del descenso: «De ahí que Dios diga cada día a los que des- 
cienden por la escala que Jacob vio en sueños: /Yo dije: todos sois dioses e hijos del Altísimo, pero morireis como hombres y caeréis como cualquiera de los príncipes $/{ }^{13}$.

Son muchas, pues, las semejanzas entre la evocación de San Jerónimo y el episodio de Berceo. Sin embargo, sobresale una diferencia, que, por lo inesperada, destaca fuertemente. En la epístola es María la primera en recibir a la joven Eustoquia. Es lógico que María, la virgen por excelencia, sea la primera en dar la bienvenida a la virgen romana. Desde un punto de vista técnico es además conveniente, puesto que a partir de la bienvenida se establece con facilidad el episodio: María, reina de las vírgenes, va escoltada por coros virginales; tras su saludo, saludan también a Eustoquia los distintos coros. Son esas intervenciones diferentes las que dan forma al momento, las que sostienen su estructura. Llama la atención, por eso, el que María no aparezca en el cielo de Oria. Esa ausencia es tan sólo aparente, sin embargo. Berceo, que utilizó la alegoría al tratar de la madre de Cristo en otras obras, la utiliza de nuevo en el episodio que estudiamos. No es que María no aparezca; es que se transforma, precisamente cuando el cielo empieza a vislumbrarse, en un prado de maravillosa riqueza, en el que un árbol se levanta - frondoso y de ramas verdes y floridas-:

Ya eran, Deo gracias, las vírgines ribadas, eran de la columpna en somo aplanadas; vidieron un buen árbol, cimas bien compassadas, que de diversas flores estavan bien pobladas.

Verde era el ramo, de fojas bien cargado, fazié sombra sabrosa e logar muy temprado; tenié redor el tronco marabilloso prado. [...]

13 «Vnde cotidie ad eos qui per scalam Iacob somniante descendunt loquitur Deus: "ego dixi: dii estis et filii altissimi omnes. Vos autem sicut homines moriemini, et tamquam unus de principibus cadetis"'», pp. 160-161. Recuérdese, por otra parte, que aparece a menudo la escalera como elemento típico de las visiones; especialmente desde la Visión de Perpetua. La escala de Jacob es también frecuente. Véase Howard Rollin Patch, El otro mundo en la literatura medieval, trad. Jorge Hernández Campos, 1950, reimpresión, Madrid, Ediciones F. C. E., 1983. 
Estas quatro donzellas, ligeras más que biento, obieron con est árbol pazer [sic] e pagamiento; subieron en él todas, todas de buen taliento, abién en él folgura, en él grant complimiento

(estrs. 43-45).

María es el prado con el que Santa Oria y las tres vírgenes tropiezan. La clave la encontramos en los Milagros de Nuestra Senora. Se trata del mismo prado que en los Milagros se explica y se describe: "Verde e bien sencido, de flores bien poblado»; «la Virgin gloriosa, madre del buen Criado» ${ }^{14}$. El árbol de Santa Oria, por otra parte, florido y de verdes ramas, representa la virginidad de María. Otra vez los Milagros nos pueden servir de clave, porque allí el color del prado significa -Berceo nos lo dice- la virginidad de Nuestra Señora: «Esti prado fue siempre verde en onestat, / ca nunca ovo mácula la su virginidat; / post partum et in partu fue virgin de verdat, / illesa, incorrupta en su entegredat» (estr. 20).

Todo lo cual tiene sentido; pues entonces no sólo es -como en San Jerónimo- María la primera en recibir a Oria, sino que además es ella la que con su virginidad sostiene y glorifica a la reclusa y a sus guías y la que las introduce por último en el paraíso.

La alegorización de María, precisamente, ilumina otro punto de importancia en relación con San Jerónimo y con la Vida de Berceo. No es la Vida de Santa Oria el primer documento que creemos inspirado en la evocación de San Jerónimo. La utilizó mucho antes San Leandro, en la España visigótica, en el tratado que sobre la virginidad escribió para su hermana Florentina. En efecto, al comenzar su trabajo exhorta San Leandro a su hermana a que considere el premio que le aguarda en el futuro: «Medita como paloma, santísima virgen, y toca con la mente la gloria que te espera en el futuro». San Leandro entonces, tratando a su manera los materiales que la evocación le suministraba, separándose hasta cierto punto de su fuente y llegando a decisiones dis-

14 Edición citada de Brian Dutton (II, 1971). Los versos utilizados pertenecen a las estrofas 2 y 19. En adelante indicaré la estrofa junto a la cita. 
tintas de las que tomaría más tarde la Vida de Santa Oria, en vez de aconsejar tan sólo un viaje imaginario o en vez de referir una visita verdadera, describe un viaje alegórico que Florentina realiza en el presente y que debe continuar realizando en el futuro: un ascenso en el presente siguiendo los pasos de las otras vírgenes, una integración en el futuro en los coros virginales. Ascenso e integración que significan, dentro de la proyección multiforme de la alegoría, el penoso esfuerzo con que la joven se incorpora, y debe seguir incorporándose, a la práctica de la virginidad dentro de la sujeción del monasticismo:

Medita como paloma, santísima virgen, y toca con la mente la gloria que te espera en el futuro. [...] Decídete, por tanto, a pensar, entiende cómo Cristo desea abrazarte, precisamente a ti que despreciaste los halagos del mundo; entiende con qué deseo te aguarda el coro de las vírgenes, cómo te contemplan éstas cuando subes al cielo con esfuerzo por los mismos lugares por donde ellas antes llegaron a Cristo. Se alegra también María, madre del Señor, cima y modelo de la virginidad, madre de incorrupción, que te concibió con su ejemplo permaneciendo íntegra, que te dio a luz con sus enseñanzas y sin conocer el dolor. Concibió al esposo y es virgen; da a luz cada día nuevas esposas y es virgen. [...] Inflámete el fuego de la llama de Cristo, y dirige tu pensamiento a los coros de vírgenes que siguen a María. Entra en esos coros, únete a ellos con el deseo de tu alma. Corre hacia allí, vuela hacia allí, allí te aguarda la corona de justicia con la que el Señor, como juez justo, te premiará en aquel día ${ }^{15}$.

De esa manera, aunque modificando el orden de la evocación de San Jerónimo y concentrando su núcleo fuertemente, se dibuja la misma agrupación, el mismo recibimiento de la epístola:

15 «Meditare ut columba, sanctissima uirgo, et mente pertracta quae in futuro te maneat gloria. [...] Age ergo cogitare, praesume intelligere quibus te amplexibus cupiat Christus, quae mundi calcasti inlecebras; quo te desiderio corus ille expectat uirgineus; quam ipsis gradibus properantem caelorum ardua uidet, quibus cohors ipsa uirginalis peruenit ad Christum. Gaudet et Maria mater Domini, apex et specimen uirginitatis, incorruptionis mater, quae uos exemplo suo genuit et manet integra, suo uos documento peperit et dolores nesciuit. Genuit Sponsum et uirgo est. Parit cotidie sponsas et uirgo est. [...] Excitet te flamma ignis huius et coros illos uirgineos, prosequentes Mariam, oculo mentis suspice: ipsis comitare coris, ipsis te animi desiderio iunge. Ibi festina, ibi propera, ibi "reposita est corona iustitiae, quam reddet tibi Dominus iustus iudex in illa die"" , Regula Sancti Leandri en Santos Padres Españoles, II, Madrid, BAC, 1971, pp. 27-28. 
Cristo, los coros de las vírgenes, por último María. No sólo eso. San Leandro toma el motivo de las dos madres que San Jerónimo había introducido y que la Vida de Santa Oria, aunque mutilándolo, había conservado, y lo toma para trasladarlo - fundiendo sus dos miembros - a la persona de María. María aparece así como madre y maestra de las vírgenes: «Se alegra también María [...] madre de incorrupción [...] que te dio a luz con sus enseñanzas y sin conocer el dolor. Concibió al esposo y es virgen; da a luz cada día nuevas esposas y es virgen". Con todo, San Leandro, en vez de preocuparse como San Jerónimo de explicar los distintos coros de mujeres castas, o en vez de describir como Berceo la sociedad del paraíso y su jerárquico andamiaje, prefiere - para sostener la decisión reciente de su hermana- señalar los pasos de la virginidad que llevan a los cielos y revelar lo que en esos pasos María significa: los pasos son la imitación de la conducta de las vírgenes ya glorificadas; María es a la vez cima y modelo, madre de incorrupción, engendradora de vírgenes y también su guía y su permanencia.

Nos parece, por eso, que la Vida de Santa Oria -inspirada sin duda en San Jerónimo- conoce también a San Leandro, toma de su tratado la alegórica visita - que se adapta admirablemente a los gustos de Berceo- y la expande mediante la escalera y la columna y también mediante la paloma que procede, en cuanto símbolo de la virginidad, de San Leandro, y que gracias a San Leandro ilumina el camino de Oria que antes entreveíamos: «Don Oria la reclusa, de Dios mucho amada [...] / catando la palomba como bien acordada, / subió en pos las otras a essa grant posada» (estr. 49). Es decir, Oria, siguiendo a la paloma de la virginidad, siguiendo los pasos - el ejemplo- de las otras vírgenes, entra con ellas en el cielo. Berceo amplía su alegoría mediante el árbol y el prado que representan a Nuestra Señora y que repiten visualmente afirmaciones del obispo de Sevilla: Maria es también cima y modelo, madre cuya integridad no se corrompe, 
engendradora, guía y descanso de las vírgenes, y por asi decirlo, puente que las conduce al paraíso ${ }^{16}$.

La visión de Santa Oria, resumiendo, al referir una visita al paraíso, obliga a las monjas de la época - para las que la obra se compone - a trasladarse al cielo con la mente en busca del provecho que a una visita así San Jerónimo había prometido: perseverancia para vencer la tentación y el desaliento. De modo semejante, la obra toda muestra, de acuerdo con lo que hace San Leandro, el trabajo y las virtudes que a lo largo de la vida deben ejercitar las vírgenes reclusas y la victoria que a la hora de la muerte les espera; anima a éstas, como resultado, a mantener la profesión que han elegido.

\section{EL POEMA Y SUS TEMAS.}

Es natural, por eso, que el poema relate la vida de una virgen y es natural también que se construya, al relatarla, sobre el concepto que de la virgen la época heredó de la patrística y de los escritos anteriores referidos de alguna forma al monacato. La virgen tradicionalmente se entendía como esposa de Cristo - «Sponsa Christi»- ${ }^{17}$, y su función como la de amar a éste, la de alabarle y contentarle. Su actividad se bifurca en dos distintas direcciones: relacionada con ella misma la primera, relacionada con Cristo la segunda. En relación con ella misma se pide una conducta virtuosa que aumente la belleza de su alma. Se busca en

16 Hay un argumento más en favor de nuestra teoria. Existe en la Real Academia de la Historia un códice del siglo XI que contiene el tratado de San Leandro y que procede de San Millán de la Cogolla (Aemilianensis, códice 53, fols. 1r-24v). Es decir, un códice del monasterio en el que escribió Berceo y en el que escribió Muño, y que por su fecha tuvo que ser conocido tanto por Muño como por Berceo. Códice que explica, a nuestro juicio, la relación con San Leandro.

17 El uso del motivo Sponsa Christi - aunque posiblemente más antiguo- se remonta a Tertuliano - véase nota 33-. Después se convierte en un lugar común que en los tratados sobre la virginidad aparece con frecuencia. «Christus virginis sponsus», dice San Ambrosio (De Virginibus, en Migne, Patrologia Latina, XVI, col. 205). Por eso San Jerónimo desea a Eustoquia: «Semper tecum sponsus ludat intrinsecus» (p. 183). Y por eso dice San Leandro a su hermana Florentina: «Habes in eo sposum quem diligas» (p. 24). 
último término el que la virgen mediante la abstinencia haga de la vida un ejercicio que, manteniendo a raya los instintos animales y rechazando lo inferior de la humana naturaleza, la eleve a un grado de perfección igual al de los ángeles. En relación con Cristo, por otra parte, se requiere caridad; es decir, amor perfecto. De ahí que la oración continua sea necesaria: en cuanto expresión de sentimientos y en cuanto medio -el más seguro en esta vida - de alcanzar la unión con el esposo. Y, como es noble el título de esposa, la humildad se recomienda: para que la humildad precisamente asegure la posesión ininterrumpida de ese título.

Nada tiene, pues, de extraño el bosquejo con que al principio del poema -en la introducción - se alude a la historia de Santa Oria y se dibujan sus virtudes. Oria huye y vive separada de los hombres, porque se entrega por completo a Cristo. De ahí que no se necesiten sus milagros, que no tenga que resolver problemas de sus prójimos. Es la esposa de Cristo y tan sólo vive para serlo. De ahí también las virtudes que se le atribuyen y la forma con que éstas se presentan. Las virtudes de Oria constituyen en la introducción tres núcleos y dan lugar en cada núcleo a un tema; es decir, a una melodía que se desarrolla a partir de entonces y que al desarrollarse sostiene la arquitectura del poema e ilumina su sentido al iluminar lo que la santa significa. El primer núcleo, apoyándose en los motivos de la abstinencia y del sufrimiento, inicia el tema de la mortificación; el cual se encarga - como se avisa entonces- de ganar la vida eterna para Oria, de conducirla al paraíso tras la muerte: «Sufrié grant astinencia, vivié vida lazrada, / por ond ganó en cabo de Dios rica soldada» (estr. 21). El segundo núcleo, reuniendo mediante dos metáforas tres virtudes, inicia el tema de la humildad, que las encarna todas, y que sirve para hacer de Oria un arquetipo cuya luz sostiene a las reclusas que viven y que sufren como ella: «Era esta reclusa vaso de caridat, / tiemplo de paciencia e de humilidat; / non amava oír vierbos de vanidat, / luz era e confuerto de la su vezindat» (estr. 22). El tercer núcleo, apoyándose en el motivo de los salmos y del poder de la plegaria, inicia el tema de la oración, que sirve para justificar las visiones que se conceden a Oria y para mantener 
- puesto que el poema consiste en la narración de esas visionesel andamiaje sobre el cual la obra se levanta: «Siempre rezava psalmos e fazié oración, / foradava los cielos la su devoción. // Tanto fue Dios pagado de las sus oraciones, / que li mostró en Cielo tan grandes visiones» (estrs. 23-24).

Oria es, pues, la esposa de Cristo: la oración la une con su esposo; la mortificación embellece su alma y asegura sus bodas tras la muerte; la humildad, la caridad y la paciencia impiden que su nobleza disminuya y la ensalzan hasta convertirla en ejemplo de las vírgenes que siguen su camino. Se originan las tres melodías de ese modo. Vamos a estudiar ahora consecutivamente cómo éstas se desarrollan y lo que éstas significan.

Tema de la mortificación. La mortificación aparece como la actividad propia de la virgen en lo que en relación con ella misma se refiere. Tiene que ver, así, con el perfeccionamiento de su alma; y, por lo tanto, es ella la que determina la gloria que espera en la vida perdurable. Por eso, la mortificación se introduce en función de la salvación. Es ella en realidad a la que se atribuyen los méritos que llevan al premio definitivo ya en la introducción a la que antes aludíamos: «Desemparó el mundo Oria, tocanegrada, / en un rencón angosto entró emparedada, / sufrié grant astinencia, vivié vida lazrada, / por ond ganó en cabo de Dios rica soldada" (estr. 21). Y desde entonces se mantiene a lo largo del poema sosteniendo sus diversas partes y dando sentido a sus diferentes elementos. Al comenzar la visión primera es la mortificación la que explica por qué se invita a Oria a visitar el paraíso: para que compruebe el valor de sus sufrimientos, el premio que con ellos gana: «Que subas a los Cielos e que veas qué gana / el servicio que fazes e la saya de lana» (estr. 33). Entonces también es la mortificación la que asegura el mérito: «Assí mandas tus carnes [le dice a Oria Santa Eulalia] e assí las castigas / que por sobir al Cielo tú digna te predigas» (estr. 36). Y la mortificación explica la presencia del primer coro de bienaventurados con el que Oria tropieza en su camino: «Tovieron en el mundo la carne apremida, / agora son en Gloria, en leticia complida» (estr. 54); es ella además la que en el coro de las vírgenes explica la razón de 
la pregunta que sobre el paradero de Urraca hace la reclusa: «Mi ama fue al sieglo ésta por qui demando, / lazró comigo mucho e a mí castigando» (estr. 72). Ella también justifica el lugar en el que se encuentran los ermitaños: «Un precioso combiento / que suffrieron por Christo mucho amargo viento» (estr. 83). Es la mortificación $-o$ por mejor decir, la necesidad de más mortificación- la que obliga a Oria a volver a la tierra después de su visita al cielo: «Díxolis [Cristo]: Piense Oria de ir a su logar [...] / aún ave un poco el cuerpo a lazrar» (estr. 102). Y es también la mortificación la que determina entonces la intervención de Cristo para certificar con su palabra el valor de los méritos que se siguen de su ejercicio: «Con lo que as lazrado ganest el mi amor» (estr. 105). Terminada la visita, cuando se presenta brevemente la vida diaria de la santa -entre la visión primera y la visión segunda-, aparece la mortificación de nuevo como el trabajo al que esa vida se dedica: «Por amor de la alma non perder tal victoria, / non fazié a sus carnes nulla misericordia» (estr. 111). La mortificación explica también el significado de la extrana alegoría en torno a la que se organiza la visión segunda: tres vírgenes se aparecen a Oria y le entregan en nombre de María un lecho cómodo y rico; lecho que, al contrastar con el incómodo camastro que la virgen utiliza, muestra el suplicio diario al que somete su cuerpo la reclusa: "Acostóse un poco, flaca e muy lazrada, / non era la camenna de molsa ablentada. [...] // Liévate de la tierra [dicen las vírgenes] que es fría e dura, / subi en esti lecho, yazrás más en mollura» (estrs. 117 y 128). La mortificación aparece, por supuesto, en las estrofas que narran la muerte de la santa: «Yaziendo la enferma en tal tribulación [...] / querié batir sus pechos mas non avié sazón» (estr. 138). De ahí que Berceo, al terminar la obra, presente la mortificación como la actividad que santifica a la reclusa, como el ejercicio que al llevarla a la dignidad donde se encuentra, permite y exige que se la alabe y se la venere: «Cuerpos son derecheros que sean adorados, / ca suffrieron por Christo lazerios muy granados» (estr. 183).

Conviene observar que en las citas antes mencionadas el tema se asocia con dos motivos: con el del sufrimiento y con el del con- 
trol de los apetitos. Queremos hacer notar con esto que el tema de la mortificación tiene en el poema dos significados: el de martirio y el de autodominio. Es decir, la virgen mediante la mortificación se convierte en mártir y mediante la mortificación también reina en sí misma.

Vamos a dedicar unas líneas a cada uno de los dos aspectos. Es el mismo Berceo el que identifica con claridad mortificación y martirio: «Martiriava las carnes [dice de Santa Oria], dándolis grant lazerio» (estr. 112). Si martirio y mortificación se identifican, y si la mortificación se presenta como la actividad propia de la virgen, resulta como consecuencia que es el martirio lo que caracteriza a la virgen y que es la virgen una mártir por lo tanto. No hay duda de que esto es lo que sucede en el poema. La Vida de Santa Oria, sin embargo, no es en este sentido innovadora: la identificación entre virgen y mártir se remonta a los primeros siglos de la Iglesia, y se repite constantemente luego en los escritos de los padres del desierto y en la literatura monástica de la Edad Media. Lo que ocurre es que en los primeros siglos de la Iglesia se atribuye al martirio el grado de perfección más grande. Los mártires, por su pasión y por su muerte, se asemejan a Cristo, y su alma, por eso, apenas separada del cuerpo, entra en el paraíso y se coloca entre los ángeles. Luchadores en la tierra contra el mundo, el demonio y la carne; milites y athletes Christi, recogen tras la muerte la preciosa corona que se guarda a los que vencen. Pero, como el martirio se considera reservado a unos pocos elegidos, se empieza pronto a distinguir y a enaltecer a los que deseosos de la corona de los mártires no llegan a alcanzarla. Se amplía así lo que se entiende por martirio, pero éste todavía se limita a un grupo privilegiado. Y como con el paso de los años las persecuciones fueron disminuyendo y terminando, nuevas teorías se fueron estableciendo, las cuales lograron que el martirio conservara su vigencia y que incluso - ampliando los límites de su alcance - representara el ideal de perfección de todo el cristianismo. San Clemente con su idea de martirio gnóstico presenta la nueva concepción a sus contemporáneos: es mártir todo el que vive una vida de sacrificio sea cual sea la forma de su muerte. 
Orígenes, sin embargo, el gran discípulo de San Clemente, es el que relaciona el martirio con los ascetas, porque los ascetas de los primeros tiempos - como los monjes que les siguieron más tarde- dan también su vida por Cristo al abandonarlo todo por seguirle. $\mathrm{Y}$ es precisamente esa renuncia al mundo lo que representa para Orígenes el ideal de perfección de los tiempos nuevos. De ahí que pudiera pasarse sin dificultad ninguna a considerar la vida del ermitaño y la del monje como un nuevo martirio, porque las dos consisten en abandonar todas las cosas ${ }^{18}$. Estas distintas opiniones y actitudes son las que los padres del yermo recogen y las que presentan muchas veces para justificar su género de vida; es decir, afirman que la lucha contra la carne y el demonio - que les obliga a mortificar su cuerpo y que les hace nuevos soldados y atletas de Cristo- es un martirio tan auténtico como el que imponen los tiranos; afirman, por otra parte, que su renuncia al mundo, su soledad eremítica, es una muerte similar a la que por su fe los mártires experimentan.

Además, también desde los primeros siglos de la Íglesia, se había colocado la práctica de la virginidad entre los más altos consejos evangélicos. El prestigio de la virginidad se debe - como explica muy bien Edward Malone (op. cit., p. 59) - a la continua batalla que para conservarla se necesita. De ahí que se viera desde muy pronto esa batalla como una especie de martirio entre los muchos que a los cristianos se ofrecían. Por eso hace afirmar San Jerónimo a Demetriada: «Coge el escudo de la fe, la loriga de la justicia, el casco de la salud, y lánzate al combate. La defensa de la castidad también tiene su martirio» ${ }^{19}$. Y puede por eso afirmar San Ambrosio: «No alabemos la virginidad porque se encuentra en el martirio, sino porque es martirio ella

18 La identificación entre monje y mártir, y las doctrinas y las actitudes que llevaron a ella han sido estudiadas. Véase, por ejemplo, Edward E. Malone, The Monk and the Martyr, Washington, D.C., The Catholic University of America Press, 1950. Véase también Malone en relación con lo que decimos sobre San Clemente y sobre Orígenes.

19 «Adsume scutum fidei, loricam iustitiae, galeam salutis, procede ad proelium. Habet et seruata pudicitia martyrium suum», Ad Demetriadem, en op. cit., II, p. 666. 
misma $\gg{ }^{20}$. Es natural, pues, que también en la Edad Media se identifique al monje con el mártir - por virgen y por mártir-y que esa identificación arrastre la de la mortificación con el martirio ${ }^{21}$. Eso, como hemos visto ya, es lo que sucede en la Vida de Santa Oria.

Al compás, por otra parte, que la mortificación se intensifica, el martirio se acentúa y aumenta como resultado la elevación del mártir dentro de la jerarquía escalonada de la ciudad celeste. No sabemos - permítasenos una pequeña digresión ahora- si es acertada o no la nueva ordenación que Isabel Uría Maqua da a las estrofas de la Vida de Santa Oria ${ }^{22}$. Nos parece que se equivoca, sin embargo, cuando, separándose de la versión tradicional, rebaja, en la visión primera, el rango de los ermitaños y coloca a éstos por debajo de los mártires. Nos parece también que se equivoca cuando adjudica a Berceo y a la Edad Media la creencia en la superioridad de los mártires sobre los ermitaños: «No se conoce ninguna tradición - ni texto-, anterior a Berceo, en la que los ermitaños ocupen en el Cielo un lugar de privilegio con relación a los mártires. Por otra parte, analizando el pasaje [de Santa Oria], comprobaremos que Berceo participa igualmente de ese sentimiento de valoración superior de los mártires con relación a los ermitaños» (p. 104). No, la Edad Media, como vimos, identificaba al mártir con el ermitaño; y, como consecuencia, el ermitaño excedía al mártir en categoría cuando le excedía en el martirio. Lo mismo sucede con Berceo. Berceo, en su Vida de Santo Domingo de Silos nos dice del protagonista: «Después fo ermi-

20 «Non enim ideo laudabilis virginitas, quia et in martyribus reperitur, sed quia ipsa martyres faciat», op. cit., col. 202.

21 Véanse por su especial interés en relación con lo que tratamos: García M. Colombas, $E l \mathrm{mo-}$ nacato primitivo, Madrid, BAC, 1974 y John Bugge, Virginitas: An Essay in the History of a Medieval Ideal, The Hague, Martinus Nijhoff, 1975. En estas obras se encontrará además la bibliografia que no es posible incluir en este artículo.

22 En El Poema de Santa Oria, Logroño, Instituto de Estudios Riojanos, 1976 y luego en Poema de Santa Oria, Madrid, Clásicos Castalia, 1981. Las citas que a continuación hacemos pertenecen al primero de los dos libros. Las dos obras, por cierto, son muy útiles e interesantes. 
tanno en que fo muy lazrado, /viviendo por los yermos, del pueblo apartado [...] / do sufrió más martirio que algún martiriado" ${ }^{23}$; lo que implica que, para Berceo, Santo Domingo, el ermitaño, supera a algunos mártires en categoría. Creemos, por lo tanto, que el orden que se atribuye al cielo en la Vida de Santa Oria ilumina no sólo el designio del poema, sino también el significado que a la mortificación se adscribe a lo largo de sus versos. Mortificación equivale a martirio, y el valor del mártir aumenta o disminuye según la mortificación se amplía o se atenúa.

Eso es, al fin y al cabo, lo que sucede con Oria. Oria es una mártir en cuanto virgen y en cuanto monja, y su martirio el más severo de los que pueden darse dentro de las reglas del monasticismo. Porque Oria es, como el poema nos io indica, una reclusa, una emparedada: «Desemparó el mundo Oria, tocanegrada, / en un rencón angosto entró emparedada" (estr. 21). No debemos, por supuesto, estudiar ahora a los reclusos. Conviene recordar, sin embargo, que aparecen en Oriente entre los siglos III y IV, y que muy pronto se extienden también por Occidente. En España habla de ellos, «eos quos in cellulis propriis reclusos», el año 646, el concilio VII de Toledo ${ }^{24}$.

Varían con el lugar y el tiempo las reglas a las que se sujetan los reclusos. En la Edad Media viven vinculados generalmente a un monasterio; no importan la denominación de éste ni el sexo de sus ocupantes. Oria, por ejemplo, como muchas emparedadas medievales, pertenece a un monasterio benedictino de varones. Viven los reclusos encerrados en una celda o habitáculo más o menos grande: aislado a veces, a veces aplicado a las paredes del templo y agrupado a otros parecidos. En alguna ocasión el poema llama casa a la celda de Oria: «Fízome en la casa de la fija entrar» (estr. 149). Dos o tres aberturas hacen de ventanas: una -si la celda comunica con la iglesia - mira al altar mayor y permite 
observar las ceremonias y recibir los sacramentos; otra sirve para que se introduzca la comida; la tercera, si existe, deja que la luz penetre. A veces, cuando se trata de varias celdas consecutivas, comunican las unas con las otras a través de una ventana que permite la conversación de los reclusos; éstos, otras veces, se relacionan con el exterior a través de un orificio que les pone en contacto con los fieles. En el caso de Oria, se ve que la clausura no es exageradamente estricta, pues la visitan su madre y su confesor; y su madre, emparedada ella misma, sale a menudo de su propia celda. Es poco lo que guardan los emparedados: varios cacharros que sirven para la limpieza, para beber o para la conservación de la comida; la cama o, mejor, unas tablas o una colchoneta. Es éste quizá el único mueble, si así puede llamarse, al que alude la $V i$ da de Santa Oria: «Acostóse un poco, flaca e muy lazrada, / non era la camenna de molsa ablentada» (estr. 117). La ropa es de lana; y es negro el velo que cubre a las mujeres la cabeza. El poema coincide también en estas dos afirmaciones: «Desemparó el mundo Oria, tocanegrada» (estr. 21); "Que veas qué gana / el servicio que fazes e la saya de lana» (estr. 33). La celda puede tener fuego o no tenerlo; y puede incluso, mediante un sistema de canalización, dejar que el agua atraviese sus paredes. Se permite algún trabajo a los emparedados; las mujeres se dedican, por lo general, al tinte, a la costura o al arreglo de ornamentos de la iglesia. La mayor parte del tiempo, sin embargo, se dedica a la oración, a la lectura y a la penitencia. La ceremonia de profesión es interesante y significativa. Recuerda, por supuesto, la de otros monjes, pues el pronunciamiento de los votos (castidad, pobreza y obediencia) es el requisito imprescindible. Por otra parte, hay una serie de elementos - distintos según el lugar y la época- que revelan el sentido de la vida de los reclusos. Sentido doble, por así decirlo. Esa vida, por un lado se relaciona con la contemplación; por otro, se identifica con la muerte, con una muerte al mundo, con un enterramiento anticipado. Por ejemplo, en relación con el primer caso, alguna vez se añade un cuarto voto (el de la estabilidad, que tradicionalmente se atribuía a la práctica contemplativa) o se recita en la misa de la ceremonia el evangelio de la Asunción (el de Marta y María: para indicar de ese modo que 
la reclusa se dedica a la contemplación como María opuesta a Marta). En relación con el segundo caso, se celebra muchas veces la misa de difuntos; se canta a menudo himnos funerales (el «In paradisum deducant te angeli», el "Commendatio animae», el «Libera me, domine»); se termina frecuentemente con el «Requiescat in pace" mientras arroja el oficiante, como si se tratara de una fosa, un poco de tierra al habitáculo, y se cierra o se tapia la puerta para siempre ${ }^{25}$.

El significado de la mortificación queda claro, por lo tanto, y la mortificación en cierto modo explica lo que Oria significa. La mortificación es virginidad, contemplación, martirio y dominio de las pasiones y apetitos; Oria es dueña de sí misma, virgen, una María contemplativa, y mártir en un sentido extremo: por su reclusión, por el tipo de vida que ha adoptado. Es decir, Oria es una especie de ermitaña dentro de la vida cenobítica.

De esa manera Santa Oria, entre monja y ermitaña, sube, gracias a su mortificación, en mérito y en jerarquía. De ahí que al comienzo se vincule con su mortificación el premio que al final recibe; es decir, su entrada en la vida perdurable. De ahí también que el premio y la mortificación se sigan vinculando a lo largo del poema, como antes hemos visto, y que, como también antes hemos visto, se espere para introducir en el paraíso a la reclusa a que acumule mediante la mortificación los méritos necesarios. De ese modo, pues, la mortificación es la que, identificándose con el martirio, determina los méritos de la reclusa. Por eso desde el comienzo -es decir, desde el principio de la visión primera - se presenta a la protagonista como igual a las tres santas que se le aparecen y le guían en su viaje. Y es Oria igual a las tres santas no sólo porque aquéllas fueron vírgenes, sino también porque todas fueron mártires. Por eso, además, el que los nombres que aparecen grabados en la silla que en el cielo espera a Oria (o en la vestidura - pues no está claro- de la joven que la

25 Véanse Rotha Mary Clay, The Hermits and Anchorites of England, Londos, Methuen, 1914, Louis Gougaud, Ermites et reclus, Vienne, Abbaye Saint-Martin de Ligugé, 1928. Hemos utilizado en nuestros párrafos anteriores especialmente el libro de Gougaud. 
guarda) sean precisamente de reclusos que mediante la mortificación y la penitencia domaron sus instintos: "Avié en ella nomnes de omnes de grant vida, / que servieron a Christo con voluntat complida; / pero de los reclusos fue la mayor partida / que domaron sus carnes a la mayor medida» (estr. 92).

El tema de la mortificación, por tanto, convirtiendo en mártir a la reclusa, haciendo a ésta virgen y dueña de sí misma, se encarga - determinando los méritos de Oria- de introducirla en el paraíso.

Tema de la humildad. El tema de la humildad, como ya notamos, comprende al iniciarse tres virtudes que sólo en la introducción se nombran y separan (además de la humildad, la caridad y la paciencia); después, en la virtud primera aparecen implicadas las dos últimas, situación que se mantiene a lo largo de la obra. También en la introducción se fija el propósito del tema: el de trascendentalizar de tal forma a la reclusa que se la convierta en modelo de los otros, en guía y en consuelo de los que viven junto a ella ( «Era esta reclusa vaso de caridat, / tiemplo de paciencia e de humilidat; / non amava oír vierbos de vanidat, / luz era e confuerto de la su vezindat,» estr. 22). Se presenta a Oria como a esposa de Cristo: amante de su esposo, esperando pacientemente el premio, sin vanagloria de su título. Se siguen los consejos de los Santos Padres que veían en la soberbia el mayor peligro que a la virginidad amenazaba. Quizá se deben precisar ahora nuestras afirmaciones.

El pecado de la soberbia fue considerado en Occidente - a partir de San Agustín sobre todo- el primero entre los capitales y además su raíz y su principio. Eso es así porque San Agustín -que interpreta literalmente el Génesis - concibe la soberbia, apartándose de los pensadores orientales, como el pecado que Adán y Eva cometieron. Es cierto, dice San Agustín, que el pecado de Adán y Eva fue un pecado de desobediencia y que consistió en comer de la manzana; pero para que éste fuera posible se necesitaba primero otro que rompiendo la perfección con que el hombre había sido revestido viciara para siempre la humana naturaleza: «Comenzaron, sin embargo, a ser malos en lo oculto para 
arrojarse luego a una clara desobediencia; pues no hubieran llegado a la mala obra si la mala voluntad no se hubiera dado primero. Pero, ¿cuál hubiera podido ser el principio de la mala voluntad sino la soberbia, puesto que la soberbia es el principio de todos los pecados? ¿Y qué es la soberbia, sino un apetito de encumbramiento perverso? ${ }^{26}$. El primer pecado de Adán y Eva no fue, pues, el comer de la manzana, sino el deseo de perverso encumbramiento que precedió a este acto. Un encumbramiento que consiste en separarse la criatura del Criador al que debe estar unida, y convertirse de algún modo en principio de sí misma ${ }^{27}$. Es ese deseo de encumbramiento el que pervirtió la humana naturaleza: «El hombre, pues, inclinado hacia sí mismo, vino a ser menos de lo que era antes, menos de lo que era cuando estaba unido a aquel que es de una manera suma» ${ }^{28}$. Y el hombre, entonces, castigado por su culpa, se convirtió en un ser carnal, condenado a la muerte como resultado - a la muerte del cuerpo e incluso a la del alma si la misericordia divina no le socorriera-: «Y siguió una justa condenación [...] por la que el hombre vino a ser carnal aun en la mente: él, que guardando lo mandado, había de llegar a ser, aun en la carne, espiritual. [...] Muerto el espíritu de manera voluntaria, tendría que morir el cuerpo de manera involuntaria; desertor de la vida eterna, quedaba condenado a una también eterna muerte si la gracia no le liberara» ${ }^{29}$. De ese modo, el pecado original determinó el destino humano para siempre, y la divi-

«In occulto autem mali esse coeperunt, ut in apertam inobedientiam laberentur. Non enim ad malum opus perveniretur, nisi praecessisset mala voluntas. Porro malae voluntatis initium quod potuit esse nisi superbia? "Initium" enim "omnis peccati superbia est". Quid est autem superbia, nisi perversae celsitudinis appetitus?" La ciudad de Dios, en Obras de San Agustín, XVI-XVII, Madrid, BAC, 1958, p. 955.

«Perversa enim celsitudo est, deserto eo cui debet animus inhaerere principio, sibi quodammodo fieri atque esse principium», ibid., p. 955.

29 «Iusta damnatio subsecuta est, talisque damnatio, ut homo qui custodiendo mandatum futurus fuerat etiam carne spiritualis, fieret etiam mente carnalis. [...] Mortuus spiritu volens, et corpore moriturus invitus: desertor aeternae vitae, etiam aeterna, nisi gratia liberaret, morte damnatus», ibid., pp. 959-960. 
na providencia tuvo que intervenir para variar ese destino. De ahí que Dios se hiciera hombre y que muriera por los hombres. Pero ese hacerse hombre y morir por los hombres es algo más que la salvación de éstos; es una acción que, por oponerse esencialmente a la soberbia, restablece en su ser primero la naturaleza humana: «Es para curar la causa de todas las enfermedades -esto es la soberbia- por lo que bajó y se hizo humilde el hijo de Dios ${ }^{30}$. La encarnación y la muerte de Cristo, por lo tanto, son actos de profunda humildad y a la vez lección de salvación que puede aprovechar a los pecadores: «Es muy útil para nosotros creer y recordar firmemente que la humildad, por la que Dios nació de mujer y por la que fue conducido a la muerte, es medicina principalísima por la que se cura el tumor de nuestra soberbia y alto sacramento que rompe las cadenas del pecado ${ }^{31}$.

De esa manera, pues, así como la soberbia aparece como el mayor de los pecados, la raíz de todos ellos, la fuente de los males y el impedimento para que el hombre sobreviva, aparece la humildad ahora como la mayor de las virtudes, la raíz de todas ellas, la fuente de los bienes y el único recurso que puede servir de fundamento a la humana pervivencia: «El hombre no hubiera perecido si no se hubiera hinchado por la soberbia; pues, según afirma la Escritura, la soberbia es el comienzo de todos los pecados (Eccl. 10. 15). Contra el comienzo de los pecados fue necesario el comienzo de la justicia. ¿Si la soberbia es, pues, el comienzo de todos lo pecados, dónde sanaríamos el tumor de la soberbia si Dios no se hubiese dignado hacerse humilde?» ${ }^{32}$.

30 «Ut ergo causa omnium morborum curaretur, id est, superbia, descendit et humilis factus est Filius Dei», Tratados sobre el Evangelio de San Juan, en op. cit., XIII (1968), p. 567.

31 «Hoc enim nobis prodest credere, et firmum atque inconcussum corde retinere, humilitatem qua natus est Deus ex femina et a mortalibus per tantas contumelias perductus ad mortem, summum esse medicamentum quo superbiae nostrae sanaretur tumor, et altum sacramentum quo peccati vinculum solveretur", Tratado sobre la Santísima Trinidad, en op. cit., V (1968), p. 417.

32 «Non enim perisset homo, nisi superbia tumuisset, "Initium" enim, sicut Scriptura dicit, "omnis peccati, superbia" (Eccli. 10, 15). Contra initium peccati, initium iustitiae necessarium fuit. Si ergo initium omnis peccati superbia; unde sanaretur tumor superbiae, nisi Deus dignatus esset humilis fieri?» Homilias (Sermo 123), en op. cit., X (1965), p. 504. 
No es de extrañar, por eso, que la humildad se exija a la esposa de Cristo. Puesto que su título es tan alto, es fácil comprender que la soberbia le persiga; y puesto que es ésta el peor de los pecados, el muro que separa al Creador de las criaturas, es fácil comprender también que se avise a la virgen del peligro que para ella supone la soberbia. La esposa debe seguir los pasos del esposo, y como la humildad es una de las virtudes características de Cristo, debe identificarse con la humildad imitando a Cristo, y, colaborando en la función de éste, puede borrar en sí el estigma de la culpa y aproximarse de algún modo a la perfección primera. «Nada es más querido a Dios que la humildad», dice Tertuliano, «nada más acepto que la modestia, nada más odioso que la vanagloria. [...] Puesto que te desposaste con Cristo [...] camina de acuerdo con la voluntad de tu esposo" ${ }^{33}$. Y recomienda San Atanasio: «Que te guardes de todo el mal de la soberbia y de la jactancia y vivas humilde según el suave ejemplo de Cristo» ${ }^{34}$. Y recuerda San Leandro: «Sé humilde según el ejemplo de tu esposo, quien, permaneciendo igual al Padre, se humilló hasta la muerte tomando cuerpo humano»" ${ }^{35}$.

De ahí que la humildad se recomiende siempre, que se defina como virtud sin la cual la virginidad no puede mantenerse. San Agustín, por supuesto, es el que al hablar de la virginidad más la requiere, hasta el punto de parecer, como señala él mismo, que abandona la virginidad para tratar de ella: «Al llegar aquí dirá alguno: Esto ya no es escribir sobre la virginidad, sino sobre la humildad» ${ }^{36}$. Y es que San Agustín - tal es la importancia que a

33 «Nihil est illi [Deo] charius humilitate, nihil acceptius modestia, nihil perosius gloria. [...] Nupsisti enim Christo [...] incede secundum sponsi tui voluntatem, De Virginibus Velandis, en Migne, Patrologia Latina, II, col. 960. Exhortatio ad Sponsam Christi, en Migne, Patrologia Latina, CIII, col. 676.

35 «Esto humilis ad normam sponsi tui, qui permanens aequalis Patri, "humiliauit se usque ad nostrum obitum, corporis humani formam suscipiens"',, p. 49.

36 «Hic dicet aliquis: "Non esto hoc iam de virginitate, sed de humilitate scribere"", De Sancta Virginitate, en op. cit., XII (1954), p. 218. 
esta última virtud concede-coloca a veces la humildad sobre la virginidad, de forma que es aquélla y no ésta la que determina en ocasiones la santidad del individuo: «Seguirán al cordero más fácilmente [...] que las vírgenes soberbias, las casadas humildes» ${ }^{37}$. Es natural, por eso, que San Agustín, magnificando las củalidades de la esposa, relacione, como relaciona la Vida de Santa Oria, la humildad con la caridad: «Si amáis [vírgenes de Dios], venid humildemente al humilde y no os separéis de él para que no caigáis» ${ }^{38}$; y añade: "Aunque sea superflua nuestra preocupación de que falte la humildad donde arde la caridad» ${ }^{39}$. Y también en San Agustín, como en la Vida de Santa Oria, se traba fuertemente la caridad con la paciencia: «Por lo tanto la paciencia de los justos viene de aquel por quien la caridad en ellos se difunde" ${ }^{40}$. Es decir, se relacionan en San Agustín las tres virtudes que en la Vida constituyen el segundo tema: «Era esta reclusa vaso de caridat, / tiemplo de paciencia e de humilidat» (estr. 22).

Las dos metáforas, como ya dijimos, convirtiendo a Oria en vaso y templo, vinculan las tres virtudes que vimos en San Agustín relacionadas. Adquieren éstas una función tectónica, pues constituyendo y desarrollando un solo tema, ayudan a disponer y a soportar la arquitectura del conjunto. De acuerdo con el plan sobre el que el poema se levanta, se desarrolla el tema en tres momentos: en la visión primera, en la visión segunda y al concluir la obra. En la visión primera la melodía de la humildad se oye a menudo; es con todo en la visión segunda en donde llega al clímax. No aparece, en cambio, en la visión tercera -o está apenas implicado-. Al terminar la obra se oye, como las otras melodías, levemente; es decir, como ocurre en la introducción -con

37 «Facilius sequuntur Agnum [...] coniugati humiles quam superbientes virgines», ibid., p. 220.

38 «Humiliter ad humilem venite [virgines Dei], si amatis, et ne discedatis ab illo, ne cadatis», ibid., p. 220.

40 «Proinde ab illo est patientia iustorum, per quem diffunditur charitas eorum», De patientia, en op. cit., XII, p., 454. 
la que el final está en correspondencia-: en la introducción se inician los tres temas, en el desenlace se terminan.

La melodía de la humildad, en efecto, abre la narración de la visión primera. Cuando las tres vírgenes invitan a la reclusa, responde ésta con las palabras del centurión del evangelio ( YYo non sería digna de veer tan grant gloria», estr. 35 ); con las palabras que servían tradicionalmente para expresar la humildad y para señalar a los humildes («Llamándose indigno», dice San Agustín del centurión, «se hizo digno, no sólo de que Cristo entrara en su morada, sino también de que entrara en su corazón» ${ }^{41}$. De esa manera se consigue realizar dos objetivos. Aparece Oria, primero,como encarnación de la humildad; aparece luego como compañera de las otras vírgenes. Oria, en cuanto encarnación de la humildad, revela lo que la santidad que se le atribuye significa: la humildad, como dijo San Bernardo, se opone al principio que había pervertido a la humana naturaleza: «Lucha la humildad contra la que es enemiga de toda gracia y comienzo de todo pecado - la soberbia- y aleja de sí y de las otras virtudes su altanera tiranía» ${ }^{42}$. La humildad es, por lo tanto, camino que lleva a Dios como alegóricamente dice la visión de Santa Oria. Por otra parte, en cuanto compañera de las vírgenes, demuestra Oria que la humildad y la virginidad se identifican. De ahí que sea éste un motivo que a lo largo de la visión no se abandona («Entraron por el Cielo que avierto estava, / alegróse con ellas la cort que y morava [...] / por essa serraniella menos non se preciava», estr. 51); motivo que se entiende sobre todo cuando reciben a la reclusa los coros virginales: «Embargada fue Oria con el recibimiento, / ca tenié que non era de tal merecimiento" (estr. 65). Es decir, lo que el episodio expresa es lo que los Santos Padres repitieron muchas veces y lo que muy bien resume San

41 «Dicendo se indignum, praestitit dignum; non in cuius parietes, sed in cuius cor Christus intraret", Homilias (Sermo 62), en op. cit., p. 118.

42 (Inimicam omnis gratiae, omnisque initium peccati debellat superbiam, et tam a se quam a caeteris virtutibus superbam illius propulsat tyrannidem», De moribus et officio episcoporum tractatus, en Migne, Patrologia Latina, CLXXXII, col. 821. 
Bernardo: «La humildad es la virtud por excelencia de la virgen $\gg{ }^{43}$.

Es que el tema no sólo sirve para sostener la visión primera, sino que explica además, como los otros, la razón de los méritos de Oria. El premio se subordina - como vimos en el tema precedente- a la mortificación, a la virginidad, al esfuerzo, en suma. Sin embargo, como dijo San Agustín innumerables veces, sin el socorro de la gracia no podrían realizarse las obras meritorias. Las vírgenes lo afirman en la visión de la reclusa: «Esto por nuestro mérito nos no lo ganariemos, / esto en que sedemos nos no lo mereciemos, / mas el nuestro Esposo, a qui voto fiziemos, / fízonos esta gracia porque bien lo quisiemos» (estr. 68). La conciencia de un hecho así es importante porque, provocando la humildad, determina hasta cierto punto la ayuda de la gracia. También San Bernardo ha precisado esta idea: «Dios da su gracia a los humildes» ${ }^{44}$. En la visión de Oria la voz del mismo Cristo lo confirma:

Sennor - dixo [Oria] - e Padre, peroque non te veo de ganar la tu gracia siempre ovi deseo. [...]

Los Cielos son muy altos, yo peccadriz mezquina [...] non trobaré en sieglo sennora nin madrina. [...]

Dixo'l aún de cabo la voz del Criador: Oria, del poco mérito non ayas baticor $[\ldots]$

Que los Cielos son altos, enfiesta la subida, yo te los faré planos, la mi fija querida (estrs. 103-106)

Con la humildad - como había comenzado- termina la visión primera; es decir, explicando cómo la grandeza de Oria consiste en no dejarse ensoberbecer por su grandeza: «Por estas visiones la reclusa don Oria / non dio en sí entrada a nulla vanagloria» (estr. 111). Todo ello de acuerdo con la tradición patrística: «Cuanto más tiene [la virgen] en sí misma de qué agradarse [dice

43 «Humilitas est summa virtus virginis», Liber de modo bene vivendi (atribuido a San Bernardo), en Migne, Patrologia Latina, CLXXXIV, col. 1.260.

44 «Quoniam humilibus Deus dat gratiam (Jac. iv, 6)», De moribus et officio episcoporum tractatus, en op. cit., col. 821. 
San Agustín] más temo que, agradándose, desagrade a aquel que rechaza a los soberbios y que a los humildes da gracia ${ }^{45}$.

El clímax tiene lugar entonces. Así como la visión primera, apoyándose en el motivo del centurión, presenta a la reclusa como humilde esencialmente, la visión segunda presenta el premio, el ensalzamiento de la santa, apoyándose en la promesa evangélica de «el que se humilla será ensalzado», que también para recomendar la humildad se utilizaba con frecuencia. Dice San Bernardo, por ejemplo: «Desciende para ascender, humíllate para que seas ensalzada [...]que quien se ensalza será humillado y quien se humilla será ensalzado» ${ }^{46}$. Es María la que se encarga de ensalzar a su devota. El ensalzamiento ocurre al invertirse el sentido de los objetos que Oria utiliza para humillarse: el camastro de la penitente se trueca en un lecho precioso en el que se ve honrada por los coros virginales. La glorificación culmina con el abrazo de María a la humilde reclusa; abrazo que la eleva a la posición más alta; es decir, hasta la reina de las vírgenes, hasta la madre de los humildes:

Dixiéronli a Oria: Tú que yazes sonnosa, levántate, recibi a la Virgo gloriosa. [...]

Recudiólis la freyra con grant humilidat: si a ella ploguiesse por la su piadat [...] cadría a sus piedes de buena voluntat. [...]

La Madre benedicta, de los Cielos Sennora [...] non lo puso por plazo nin sola una hora, fue luego a abraçarla a Oria la serora (estrs. 120-121 y 123)

Acaba la melodía en el desenlace, cuando el poema se concluye. Muere Oria y sus restos se colocan en una pobre sepultura («Como merescié ella non de tal apostura,» estr. 181). Humilde,

45 "Quo magis inest unde sibi placeat, eo magis vereor ne sibi placendo illi displiceat, qui "superbis resistit, humilibus autem dat gratiam"», De sancta virginitate, en op. cit., p. 190. humiliat, exaltabitur (Matth. xxiii, 12; Luc. xiv, 11 et xviii, 14)", Liber de modo bene vivendi, en op. cit., col. 1.260 . 
como en vida, reposa tras la muerte. Sin embargo, y es eso lo que el desenlace enseña entonces, no es la tumba la que honra los despojos, sino los despojos a la tumba. Y así los restos de la humilde penitente aparecen como objeto de adoración, convirtiendo en relicario el monasterio de San Millán de Suso.

El tema de la humildad, por lo tanto, trascendentalizando las virtudes de la reclusa hace de ésta modelo y abogada de las otras vírgenes.

Tema de la oración. La oración también aparece en el poema como actividad fundamental de Santa Oria. Coincide así la Vida con las doctrinas que sobre la oración habían pronunciado los padres de Oriente y de Occidente y además los padres del desierto: la oración es la actividad esencial del monje, y debe ser continua, como San Pablo había advertido a los tesalonicenses: «Sine intermissione orate» $(\mathrm{I}, 5,17)$. De ahí que Casiano definiera el fin del monje como la oración precisamente: «El fin del monje [...] consiste en una oración perfecta» ${ }^{47}$, en una oración que sin interrupción debe ejercerse («Exercere sine intermissione»). Los monjes del desierto, por eso, se preocuparon de las fórmulas oracionales, del carácter de la plegaria, de las invocaciones y de las jaculatorias, de la hora de la oración y de la postura del orante. Todo ello ha sido estudiado por Colombas ${ }^{48}$. Además, la lectura de los libros sagrados y la oración en sus diferentes manifestaciones - recitación de plegarias y de salmos, meditación, entonación de himnos- se consideraban como una conversación con Dios, como un diálogo. Por eso la vida del monje se regulaba para que alternaran en ella la oración y la lectura. Es decir, para que hablara el monje con Dios y para que Dios hablara con el monje. San Jerónimo recoge la idea cuando advierte a Eustoquia: «Rezas, hablas con tu esposo; lees, él habla contigo». Y San Leandro recomienda a su hermana Florentina: «Que sea en ti asidua la lectura y la oración continua. Distribuye tu tiempo y

47 «Finem monachi [...] in orationis consummatione consistere», Collationes, en Migne, Patrologia Latina, XLIX, col. 779. 
tu trabajo de tal forma que puedas rezar después de tu lectura y leer después de tus plegarias ${ }^{49}$.

Así sucede en la Vida de Santa Oria. La oración aparece como el ejercicio de las vírgenes; recuérdese, por ejemplo, a éstas cuando salen en el cielo al encuentro de la emparedada: «Issieron recibirla con responsos doblados» (estr. 64). Por eso la oración se presenta también como el ejercicio de Oria. Así lo señalan las palabras con que Cristo despide a la reclusa al terminar la visión primera: "Torna a tu casiella, reza tu matinada» (estr. 107). Lo señala también la estrofa 112 al explicar las actividades de Oria: «Martiriava las carnes dándolis grant lazerio, / cumplié días e noches todo su ministerio, / ieiunios e vigilias e rezar el salterio». Lo señala María, añadiendo que es la oración el ejercicio constante de la santa: «Preguntóla [Oria] si era ella santa María; / Non ayas nulla dubda — dixo'l- fijuela mía, / yo só la que tú ruegas de noche e de día» (estr. 124). Esa oración que acompaña en vida a la reclusa, la acompaña también a la hora de la muerte: «Yaziendo la enferma en tal tribulación, / maguera entre dientes fazié su oración» (estr. 138).

La oración, pues, aparece en el poema -y de acuerdo con una larga tradición- como actividad fundamental en la vida de la virgen. Sin embargo, a diferencia de la mortificación - que relacionaba a ésta con sí misma-, la oración la relaciona con Cristo, poniendo en contacto, de ese modo, al esposo con la esposa. Porque la virgen, que necesitaba sujetarse a todo tipo de martirios para hacerse digna del esposo, debe amar a éste. Y la oración es amor; de acuerdo, también, con una tradición muy larga. De ahí las palabras con que San Jerónimo se dirigía a Eustoquia; palabras que poco antes comenzamos a citar y que ahora acabaremos: «Rezas, hablas con tu esposo; lees, él habla contigo. Y cuando el sueño te oprimiese entrará su mano por las grietas de

49 «Lectio tibi sit adsidua iugisque oratio. Diuidantur tibi tempora et officia ut, postquam legeris, ores et, postquam oraueris, legas», p. 53. 
tu cuarto y tocará tu vientre, y te levantarás temblando y diciendo: Herida estoy de amor ${ }^{50}$.

De ahí que la oración, en cuanto amor, sea el medio de comunicar con el amado, de entrar en contacto con él en este mundo. De ahí también que el poema, así como encargaba a la mortificación llevar a Oria al cielo tras la muerte, encargue a la oración llevarla al cielo en esta vida. Y el autor, para que el tema de la oración realice la función que le encomienda, lo convierte en la motivación de las visiones: «Tanto fue Dios pagado de las sus oraciones, / que li mostró en Cielo tan grandes visiones (estr. 24). De esa forma cobra el tema una función segunda, muy importante en lo que a la elaboración del poema se refiere: al compás que se va desarrollando van apareciendo las visiones; las cuales constituyen la arquitectura, el cuerpo de la obra, como antes hemos afirmado y como han afirmado muchos críticos ${ }^{51}$.

Por otra parte, la oración, al convertirse en el elemento mediante el cual comunican los esposos y en la motivación de las visiones, confiere a éstas un peculiar carácter. No se trata tan sólo de contemplar escenas celestiales, sino también de una contemplación que relaciona con Cristo a Santa Oria. Se trata de una contemplación mística incipiente; incipiente, porque lo místico se limita a la tradición que respalda las visiones. Es que Berceo no se distingue por una sensibilidad mística $-\mathrm{y}$ al parecer tampoco el autor antiguo-, sino por un deseo de particularizar las abstracciones, de humanizar personajes y experiencias. Recordemos tan sólo, pues no es el momento de extenderse en ello, la presentación de María en los Milagros de Nuestra Señora, el empeño y

50 «Oras: loqueris ad sponsum; legis: ille tibi loquitur et, cum te somnus oppresserit, ueniet post parietem et mittet manum suam per foramen et tanget uentrem tuum, et tremefacta consurges et dices: "uulnerata caritatis ego sum"», p. 183.

51 Punto éste importante para diferenciar la Vida de Santa Oria de las otras vidas de Berceo. Nicasio Salvador Miguel, por ejemplo, se apoya en esa diferencia para definir el carácter esencial del libro («Mester de clerecía», en Historia de la literatura española, I, Madrid, Guadiana, 1974, pp. 140-141); Domingo Ynduráin, por su parte, aprovecha la misma diferencia para indicar lo que de original en la literatura española tiene la obra de Berceo («Algunas notas sobre Gonzalo de Berceo y su obra», Berceo, 90 [1976], p. 35). 
el éxito de transformarla en madre, la necesidad de dibujarla no como la Gloriosa del Románico - aunque todavía Berceo así la nombre-, sino como la piadosa vecina cuyo amor y cuya piedad garantizan en el Gótico su ayuda y su socorro.

Que la oración y la contemplación se identifican era conocido desde antiguo. Casiano, por ejemplo, las vincula con terminología semejante a la que se utiliza en el poema de Santa Oria: «Que la mente se vea tan libre del peso de la carne que pueda remontarse cada día al mundo espiritual, hasta que toda su actividad y todos los deseos de su corazón se conviertan en una oración única y continua» ${ }^{52}$.

Es natural, por lo tanto, que las doctrinas que ahora nos ocupan nos lleven, como nos llevaron antes las referentes a la mortificación, a la contraposición entre vida activa y vida contemplativa. Es natural también, pues en ambos casos se coloca sobre la primera la segunda, que aparezca el monje -como antes los reclusos - ejemplarizando la vida contemplativa, llegando - como María opuesta a Marta - a la comunicación divina mediante la oración y a través de las visiones. Esta contraposición aparece ya en la Historia monachorum in Aegypto para recomendar la oración y la contemplación precisamente: «Hijos, buscad el silencio, ejercitándoos sin cesar en la contemplación, para que en vuestras plegarias guardéis puro vuestro espíritu. Sin duda tiene también mérito el asceta que se ejercita continuamente en el mundo y se aplica a las buenas obras [...] con todo, es mejor y mayor el contemplativo que cambió la actividad por el conocimiento. [...] Después de olvidarse y de renunciar a sí mismo, persigue las cosas del cielo" ${ }^{53}$. Y es que la oración penetra los cielos como asegura San Bernardo repitiendo versículos del Eclesiástico: «Oratio iusti penetrat caelos» (véase la nota 56). Pueden, por

52 «Ut eo usque extenuata mens ab omni situ carnali ad spiritalia quotidie sublimetur, donec omnis ejus conversatio, omnis volutatio cordis, una et jugis efficiatur oration, Collationes, en op. cit., col. 828 .

53 Edición crítica del texto griego y traducción al francés de André-Jean Festugière, Bruxelles, Société des Bollandistes, 1971, pp. 26-27. 
eso, los que a la oración se dedican horadar las murallas celestiales y con la ayuda de los bienaventurados a los que se invoca recorrer el paraíso: «Puede, así, cada uno de nosotros, incluso durante esta vida mortal, horadar en el lugar que quiera esa muralla celeste. Y puede hacerlo o visitando a los patriarcas o saludando a los profetas o mezclándose al grupo de los apóstoles o introduciéndose en los coros de los mártires. Puede hacerlo también, si a ello le inclina su devoción, recorriendo jubilosamente las mansiones de las bienaventuradas virtudes: desde los más altos serafines y querubines hasta los más pequeños de los ángeles» ${ }^{54}$. Eso es, pues, lo que hace Santa Oria en la visión primera; en la visión que, como hemos explicado, se construye con materiales procedentes de San Leandro y de San Jerónimo y quizá, diríamos ahora, también de San Bernardo.

Es decir, porque la oración se había identificado con la contemplación tradicionalmente, puede convertirla la Vida de Santa Oria en motivación de las visiones. Las visiones de la santa, por otra parte, son como aquellas a las que alude en nuestra cita San Bernardo: contemplación de escenas celestiales. Conservan esas visiones, a pesar de todo, y aunque sea de manera muy desdibujada, su función originaria: sirven para relacionar de alguna forma a Oria con Cristo, con su esposo; o mejor, con el que debe ser su esposo después de que su muerte haya ocurrido. Porque en Berceo, esa unión, que es importante en cuanto define y testimonia el carácter de la santa - «Sponsa Christi»-, no debe ocurrir en esta vida, sino en la vida futura, en la vida perdurable. Así pues, desaparecen del poema las pretensiones místicas. Es que para Berceo, ajeno, como apuntamos, a todo misticismo, la unión entre la esposa y el esposo significa únicamente el premio de un trabajo: un premio y un trabajo importantísimos, puesto que representan el eje central de la conducta y de las motivacio-

54 «Licebit itaque unicuique nostrum, etiam hoc tempore nostrae mortalitatis, cavare sibi, quacumque parte volet supernae maceriae: nunc quidem Patriarchas revisere, nunc vero salutare Prophetas, nunc senatui etiam misceri Apostolorum, nunc Martyrum inseri choris; sed et beatarum Virtutum status et mansiones, a minimo angelo usque ad Cherubim et Seraphim, tota mentis alacritate percurrendo lustrare, prout quemque sua devotio feret», Sermones super Cantica Canticorum (Sermo 62), II, Roma, Editiones Cistercienses, 1958, p. 155. 
nes de la santa; presentes, por eso, desde el comienzo de la historia. Es paradójico lo que sucede: Oria, la María contemplativa de la tradición monástica, se trueca en cierto modo en la Marta activa que representa el ascetismo: ascetismo opuesto a misticismo como en la Historia monachorum vimos antes. Lo cual es natural; al fin y al cabo, lo que interesa en el poema es el premio que consigue una vida de mortificación y de ascetismo. De ahí precisamente el que Oria no pueda contemplar a Cristo en sus visiones («Udió fablar a Christo en essi buen conviento; / mas non podió veerlo a todo su taliento, / ca bien lieve non era de tal merecimiento», estr. 88). De ahí también que la silla que en el cielo se reserva a la reclusa y que se explica en el texto como el premio que ha de ganar con su trabajo (estr. 96) se transforme en el tálamo en el que un día, tras la muerte, debe unirse con su esposo. Tálamo más interesante para ella, nos parece, por lo que tiene de premio que por lo que tiene de unión con Cristo: «Si como tú me dizes - díxoli santa Oria- / a mí es prometida esta tamanna gloria, / luego en esti tálamo querría seer novia. [...] // Recudióli la otra como bien razonada: / Non puede seer esso, Oria, esta vegada [...] / fasta que sea toda tu vida acabada» (estrs. 97-98).

La oración, pues, en cuanto representa una actividad esencial de Oria y en cuanto sirve para relacionar con Cristo a la reclusa, se convierte en tema que sustenta la arquitectura del conjunto. Su melodía, en efecto, se escucha fuertemente en las estrofas primeras de la obra, en donde se entrelazan tres motivos que descubren alguno de sus aspectos principales y que aseguran el ejercicio de su función tectónica. Es decir, la melodía explica en qué consiste la actividad oracional de la reclusa («Siempre rezava psalmos e fazié oración», estr. 23); revela el poder de la plegaria de acuerdo con las afirmaciones de San Bernardo que citamos antes («Foradava los cielos la su devoción», estr. 23); y supedita a la oración la próxima aparición de las visiones («Tanto fue Dios pagado de las sus oraciones / que li mostró en Cielo tan grandes visiones», estr. 24). De ahí que resuene el tema al principio de cada uno de los núcleos motivando e introduciendo la visión correspondiente. Se nos dice en la visión primera: «Tercera noche era después de Navitat, / de Santa Eugenia era festividat. 
[...] // Después de las matinas, leída la lectión [...] / vido en poca d'hora una grant visión» (estrs. 25-26). Se nos advierte en la segunda: «Tercera noche ante del mártir Saturnino [...] / vínoli una gracia, mejor nunca li vino. [...] // Serié la meatat de la noche passada, / avié mucho velado, Oria era cansada» (estrs. 116117). Se introduce así la visión tercera: «En cuita yazié Oria entro en su casiella, / sedié un grant conviento de fuera de la ciella, / rezando su salterio cascuno en su siella. [...] // Traspúsose un poco ca era quebrantada, / fue a mont Oliveti en visión levada» (estrs. 137 y 139).

$\mathrm{Y}$ en las tres visiones - aunque de distinta manera y en proporción distinta- adquiere el tema un especial sentido. En la visión primera es donde éste más se expande y desarrolla. Comienza por establecer la importancia de la oración, su fuerza trascentente. Aprovecha para ello el motivo de San Bernardo que en la introducción se utilizaba: el de que la oración horada el cielo. Se acude para hacerlo a la alegoría del prado y la columna: frente a ese prado, cuando Oria y las tres vírgenes descansan, el cielo se ilumina a través de unas "ventanas horadadas» («Estando en el árbol estas duennas contadas, / sus palombas en manos, alegres e pagadas, / vidieron en el cielo finiestras foradadas, / lumnes issién por ellas, adur serién contadas,» estr. 46). Aparecen después tres ángeles que transportan al cielo a las tres vírgenes y con ellas a Oria que las sigue: «Issieron tres personas por essas averturas, / cosas eran angélicas con blancas vestiduras. [...] // Prisieron estas vírgines estos santos varones [...] / metiéronlas más altas, en otras regiones. [...] // Don Oria la reclusa de Dios mucho amada [...] / subió en pos las otras a essa grant posada» (estrs. 47-49). Se trata, por supuesto, del motivo que la introducción tomó de San Bernardo, pero ampliado lo suficiente para dar sentido a la oración y al episodio. San Bernardo habla también de la paloma y de las aberturas horadadas para interpretar la visita al cielo de manera semejante a como lo había hecho para Eustoquia San Jerónimo. Cobra esta visita, por otra parte, una función idéntica, pues anima a los que la practican con la evocación del premio. Dice San Bernardo: «No sólo en los agujeros de las pie- 
dras encuentra refugio la paloma, sino también en los huecos de los muros» ${ }^{55}$. Los muros significan para San Bernardo «la congregación de los santos»; puede, por eso, añadir en seguida: «Porque aquella sagrada muralla cede al deseo del alma [...] cede a la pura contemplación, cede a la oración repetida, pues la oración del justo penetra los cielos [...] Es que hay cielos santos, vivos y racionales que cantan la gloria de Dios, que se inclinan gustosamente hacia nosotros cuando se lo pedimos y que, escuchando nuestras peticiones, nos reciben en su corazón cada vez que les llamamos con intención recta» ${ }^{56}$.

Estos cielos, pues, que la oración horada; estos ángeles y bienaventurados que descienden a ayudar a subir a las alturas a los que ruegan, son los mismos que descienden a la celda de la reclusa y los que la guían en su viaje; un viaje, recuérdese, que garantiza, por lo que en él debe descubrirse, que ha de ser glorioso el final definitivo. Tal es el poder de la plegaria: «Tú mucho te deleytas en las nuestras passiones, / de amor e de grado leyes nuestras razones; / queremos que entiendas entre las visiones / quál gloria recibiemos e quáles gualardones» (estr. 54). No es de extrañar, por eso, que la silla que representa en el paraíso el galardón de Oria se vincule estrechamente a la plegaria. Ella simboliza la oración de la virgen antes y después del triunfo; antes, en cuanto que con la oración debe conseguirse; después, en cuanto que la oración será el oficio de la virgen en la vida perdurable ${ }^{57}$.

Otro tanto sucede en la visión segunda; es decir, cuando María se aparece a la emparedada. Podría definirse la visión -obsérvese que es muy breve ahora: veintitrés estrofas- como

55 «Non tantum in foraminibus petrae tutum reperit columba refugium: reperit et in cavernis maceriae», ibid., p. 154.

56 «Cedit nempe [...] pia maceries desiderio animae, cedit purae contemplationi, cedit crebrae orationi. Denique "oratio iusti penetrat caelos" [...] sed sunt caeli sancti, vivi, rationabiles, qui enarrant gloriam Dei, qui favorabili quadam pietate nostris se votis libenter inclinant, et sinuatis ad tactum nostrae devotionis affectibus in sua nos recipiunt viscera, quoties digna ad eos intentione pulsamus», ibid., p. 155.

57 Véase el interesante artículo de Paolo Cherchi «La "siella" de Oria», Cultura Neolatina, 33 (1973), pp. 208-216. 
representación gráfica de la oración perfecta. Oria, que según María dedica constantemente a ella sus plegarias, lo que pretende conseguir entonces es la comunicación con la Gloriosa: «Si a ella ploguiesse por la su piadat [dice Oria de María] / que yo plegar podiesse a la su magestat, / cadría a sus piedes de buena voluntat» (estr. 121). Y la reclusa consigue su propósito: «La Madre benedicta, de los Cielos Sennora [...] / fue luego abraçarla a Oria la serora» (estr. 123). Es cierto que esa comunicación no tiene que ver con Cristo, sino con su Madre, con María; sin embargo, procura Berceo explicar la visión cuando comienza, y explica, al explicarla, las otras visiones de la obra. Visión, dice Berceo, significa comunicación con Dios precisamente. Eso es lo que consigue ahora y siempre Santa Oria: «En essi mes onzeno vido grant visión, / tan grande com las otras, las que escriptas son; / non se partié Dios d'ella en ninguna sazón / ca siempre tenié ella en El su coraçón» (estr. 115).

La visión tercera, muy breve y mutilada - tan sólo cinco estrofas-, nos produce una impresión, sin embargo, parecida. Es transportada Oria al Monte de los Olivos; es decir, al lugar que simboliza la oración por excelencia, al lugar a donde Cristo acostumbraba retirarse, y al que se retiró para orar poco antes de su muerte; al lugar desde el que subió a los cielos para unirse para siempre con su Padre. La función de la visión es clara: a ese lugar de la oración se retira también antes de su muerte Santa Oria, y desde ese lugar ha de subir al cielo para unirse con Dios eternamente: «Traspúsose un poco ca era quebrantada, / fue a mont Oliveti en visión levada. [...] // Vido por essa sombra muchas gentes venir [...] / querién si fuesse tiempo al Cielo la sobir» (estrs. 139 y 142). Por eso la melodía de la oración se amplía cuando poco después se describe la muerte de la reclusa; es que ha llegado por fin la unión de los esposos, el momento tan ansiado del premio y del descanso: «Fue'l viniendo a Oria la hora postremera [...] / alçó la mano diestra de fermosa manera, / fizo cruz en su fruente, santiguó su mollera, // Alçó ambas las manos, juntólas en igual, / como qui riende gracias al Rei spirital [...] / rendió a Dios la alma, nunca más sintió mal» (estrs. 176177). 
El tema de la oración, por lo tanto, no sólo certifica la santidad de Oria, sino que explica también su reclusión y su aislamiento: su falta de interés - aparente al menos- por sus prójimos. Oria es una virgen, una esposa de Cristo y, como esposa, debe dedicarse al esposo por entero, debe olvidar - como María opuesta a Marta - todos los otros intereses. De ahí que no quepan en la vida de Oria ni circunstancias que la sitúen entre los otros hombres, ni milagros - mientras vive o tras su muerteque la hagan estar pendiente de sus prójimos. Toda su atención, todo su penosísimo trabajo se reservan tan sólo para Cristo, como las reglas hagiográficas disponen y como el concepto de virgen dictamina.

Es a esa negación absoluta de sí misma y a esa entrega total y generosa a las que se atribuyen la grandeza de Oria. Y esa grandeza - que deriva del aislamiento, por lo tanto, y que justifica el aislamiento - sirve paradójicamente al autor -coronando su trabajo y satisfaciendo sus deseos- para poner a la reclusa en contacto con los hombres y para convertirla en intercesora de los que a ella se encomiendan. Así es cómo la invocación final -transcendentalización de la que se escucha en el principio (estr. 3) - presenta a Santa Oria, a Santa Oria ya glorificada y en compañía para siempre de su madre Amuña (en el paraíso y en el monasterio de San Millán de Suso): "Cuerpos son derecheros que sean adorados, / ca suffrieron por Christo lazerios muy granados; / ellas fagan a Dios ruegos multiplicados / que nos salve las almas, perdone los peccados» (estr. 183).

Se ensalza así hasta el máximo a la humilde emparedada, se trueca en trascendente - mediante la oración - lo inmanente de su mortificada vida recluida, se reviste a la esposa con todos los privilegios que sus responsabilidades merecen, de forma semejante a como había hecho San Leandro con su hermana Florentina: «si tú eres acepta a Dios, si tú te desposares en casto matrimonio con Cristo, si tú te abrazares a Cristo con el abrazo del 
perfume de la virginidad, ciertamente, recordando a tu pecador hermano, obtendrás para sus culpas el perdón que solicitaresn "*.

La invocación con que termina la Vida de Santa Oria aparece, pues, como resultado del tratamiento de los temas y de la arquitectura del conjunto, como testimonio de la utilidad del ejercicio que propone San Jerónimo y que realiza la visión primera, como demostración de la eficacia de los consejos que el poema ofrece a sus lectores y en especial a las reclusas de la época.

58 «Si tu accepta Deo es, si tu casto cubili cum Christo cubaueris, si tu Christi amplexibus fragrantissimo uirginitatis odore inhaeseris, profecto peccatoris memor fratris, obtinebis pro reatu germani indulgentiam quam poposceris», p. 29. 